"نشريه علوم زراعى ايران"

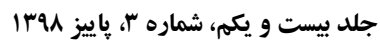

مقاله يُوهشى

اثر محلولياشى عناصر ريزمغذى بر عملكرد و كيفيت روغن دانه كلزا (Brassica napus L.) رقم

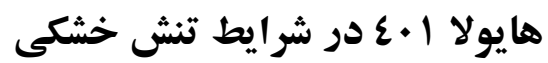

Effects of foliar application of micronutrients on seed yield and oil quality of canola (Brassica napus L. cv. Hyola401) under drought stress conditions

$$
\text { سيداحمل كلانتر احملى 'و احمل اعلى شوشى دزفولى }
$$

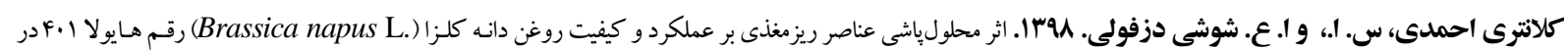
شرايط تنش خشكى. نشريه علوم زراعى ايران. اr(r):

به منظور ارزيابى اثر تنش خشكى ناشى از قطع آييارى و محلول ياشى عناصر ريزمغذى روى، بُر و منكنز بر عملكـرد دانس، ميـزان

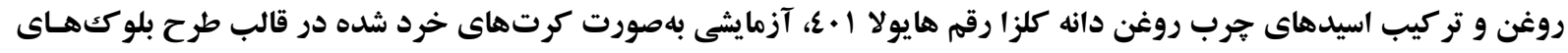

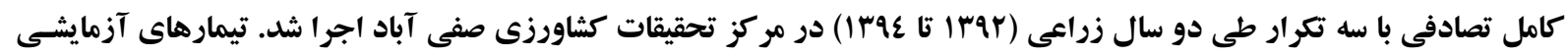

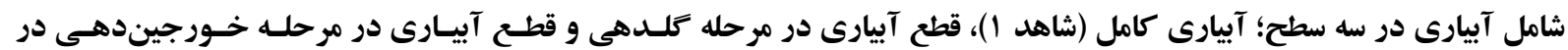

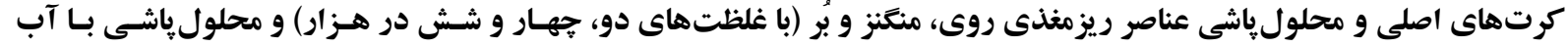

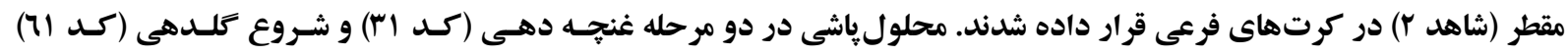

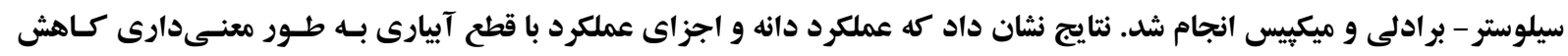

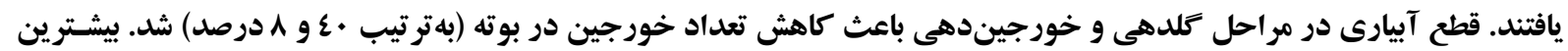

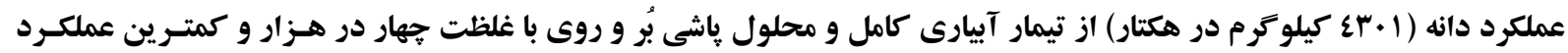

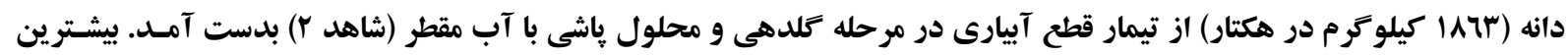

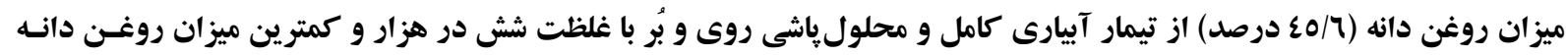

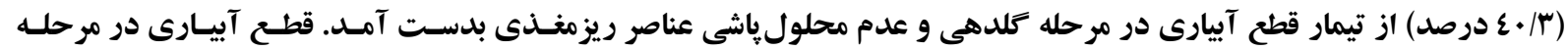

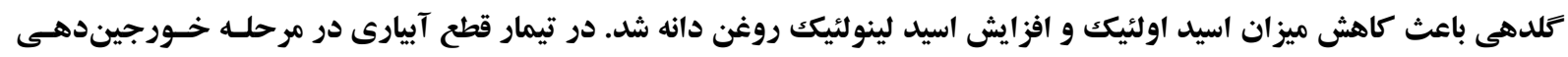

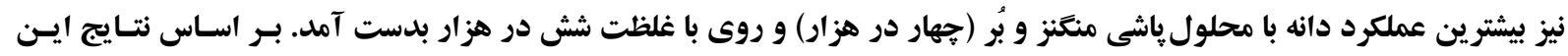

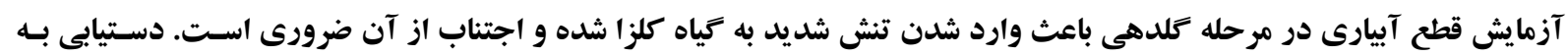
عملكرد مناسب دانه كلزا با اجراى آبيارى كامل و محلولياشى بُر و روى با با غلظت جهار در هزار امكانيذير است.

وازههاى كليدى: اسيد اولئيك، بُر، تنش خشكى، روى، كلزا و منكنز.

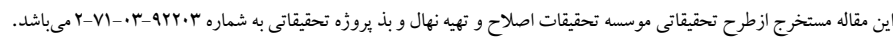

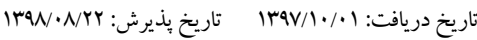

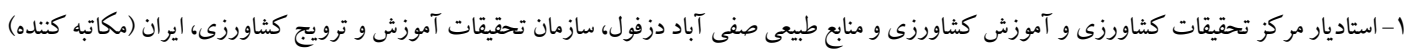

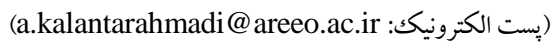
r-استاديار مركز تحقيقات كشاورزى و آموزش كشاورزى و منابع طبيعى صفى آباد دزفول، سازمان تحقيقات آموزش و ترويج كشاورزى، ايران 
موضوع نيز بدليل كـاهش گشـود گكى روزنههـا و تعـرق اسـت (Hajiboland and Amirazad, 2010). نتـايج تحقيقـات نشـان داده اسـت كـه محلـول پياشـى مقــادير

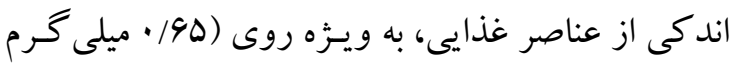

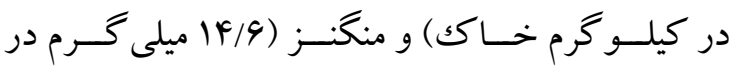

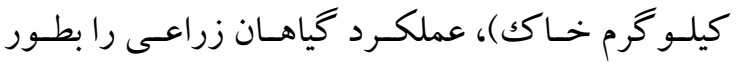

معنى دارى افزايش مىدهد (Sarkar et al., 2007).

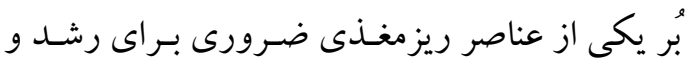

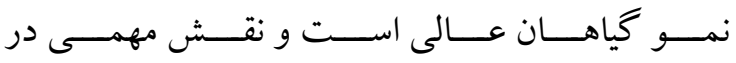
ساختمان ديواره سـلول، بايسـارى غشـاى سيتويلاســم و

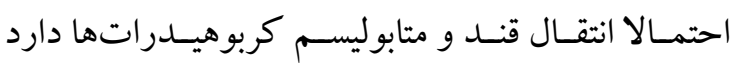

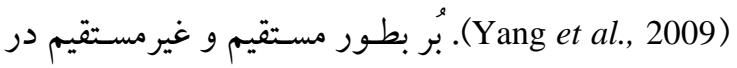

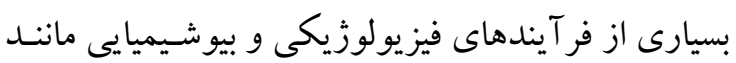

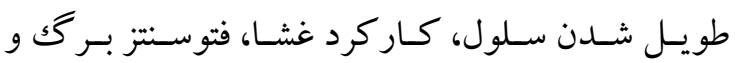

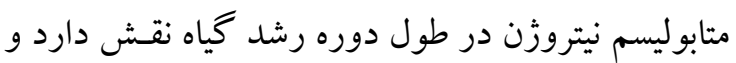
در نتيجه باعث بهبود معنىدارى عملكرد و كيفيت كيـاه مىشود. با توجه به نقش ريشهها در جذب باعب آب، عناصر غذايى و حفظ تعادل آبى گياه، سيستم ريشهاى كسـترده

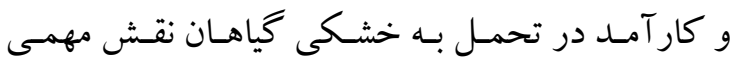
دارد. كمبـود بُّـر باعـث اخـتلال در تشـكيل و كـار كرد

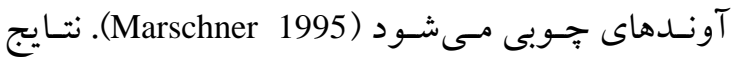
تحقيقات ناديـان و همكـاران (Nadian et al., 2010) در

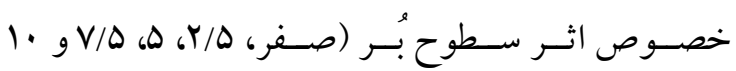
كيلو گرم در هكتار) بر عملكرد دانـه كلـزا نشـان داد كـهـ

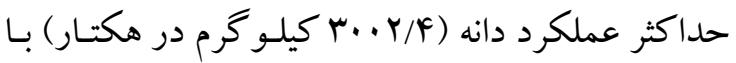

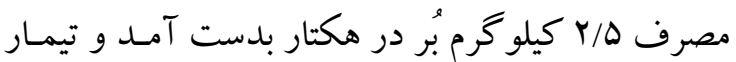

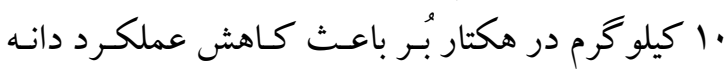

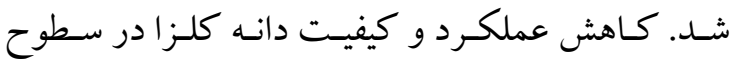

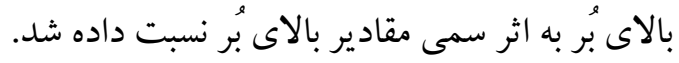

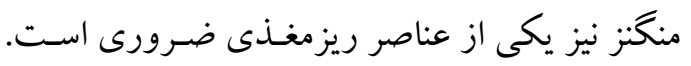

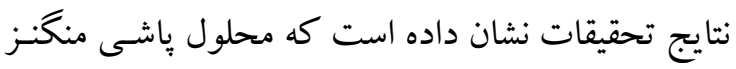

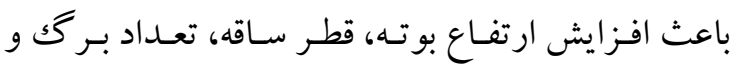
سطح برگك در گياه آفتابخردان شد. محلـول باشسى رئز

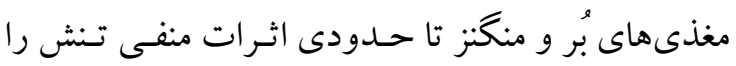

\section{مقدمه}

كلزا يكى از دانههاى روغنى مهم محسوب مسى شـود

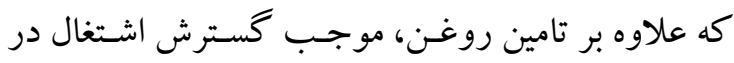
بخش صنعت شده و كنجاله مورد نياز طيور رانيز تـامين موجن

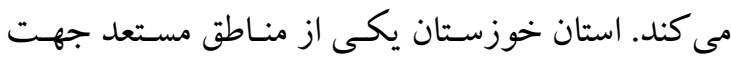

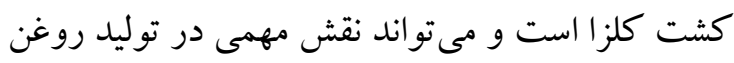

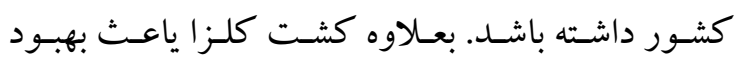

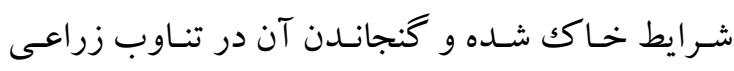
باعث بِيدارى توليد ساير محصـولات زراعى از جملـه كندم خو اهد شد.

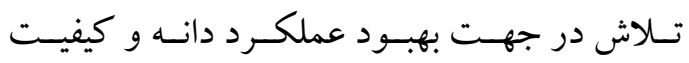

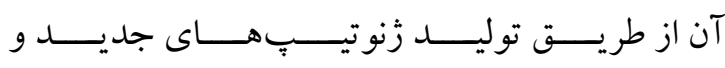

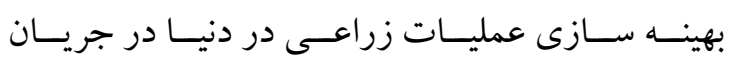
اسـت (Movahhedy-Dehnavy et al., 2009). تعيسين

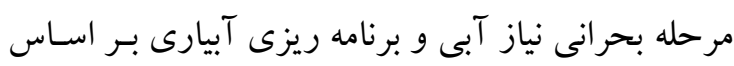

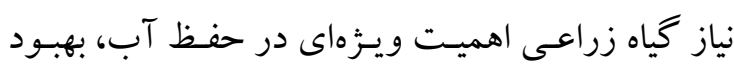
اجـراى آبيـارى و يايسـدارى كثـاورزى فاريـاب دارد

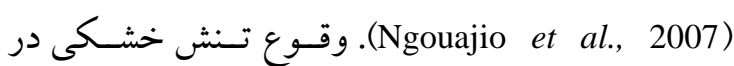
مراحل مختلف فنولوزيكى گياه كلزا اثرات متفاوتى بـر

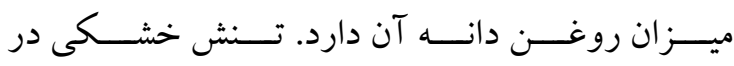

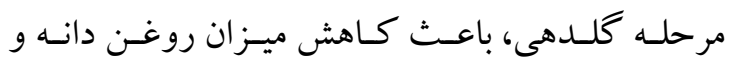

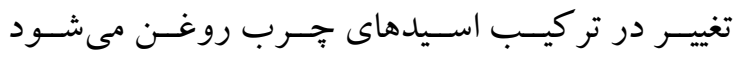

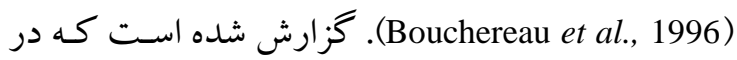
شـرايط تسنش خشـكى، تحسر كك عنصـر روى در كيـاه

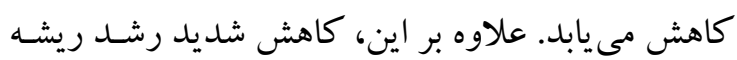

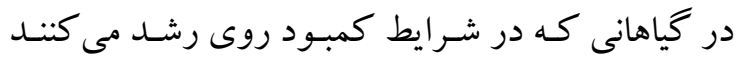
بسيار محسوس بوده و در جذب ساير عناصر غذايى نيز

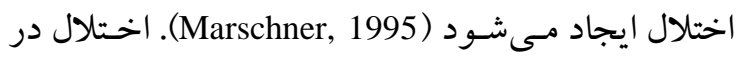
رشد در اثر كمبود روى و تنش خشكى إخى، بـدليل آسـيب

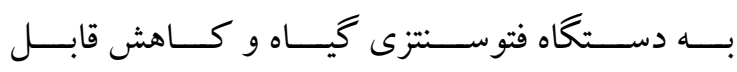

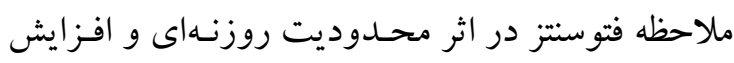

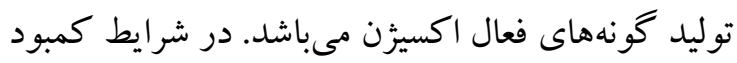
روى و تنش خشكى، فقط بخش اندكى از روى جـذب فئب

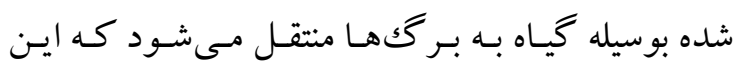




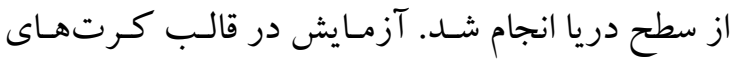

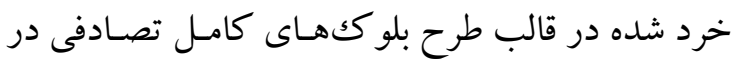

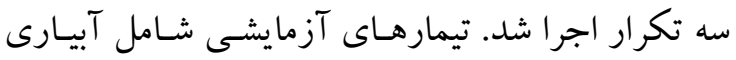

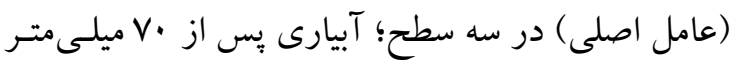

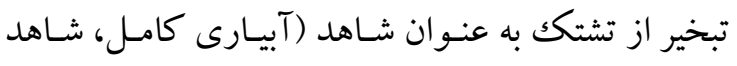

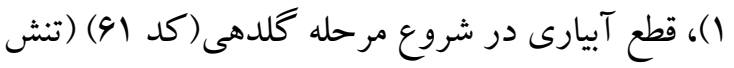

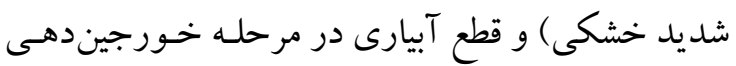

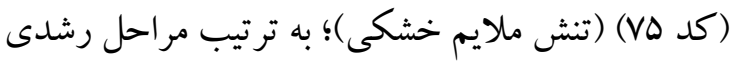

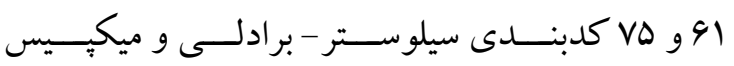
كياه كلزا (Sylvester-Bradley and Makepeace, 1984)

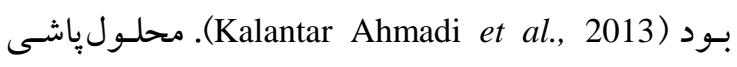

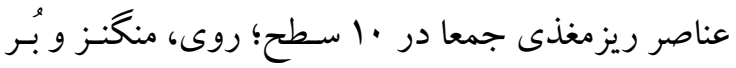

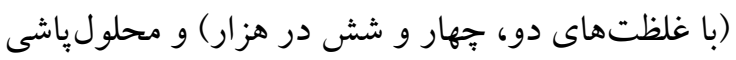

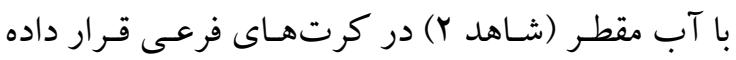

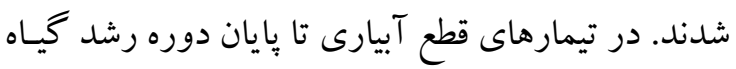

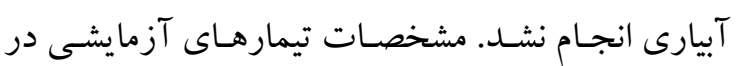
جدول يكك ارائه شده است.
كاهش داده و باعث ايجاد تعادل تغذيسهاى در گيـاه نيـز مىشود (Jabeen and Ahmad, 2011).

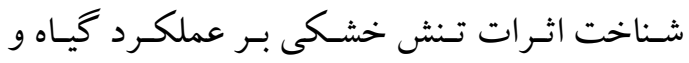

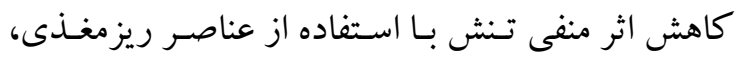

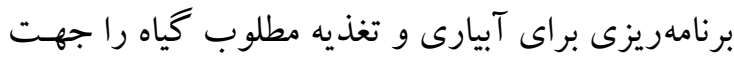

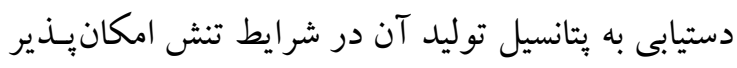

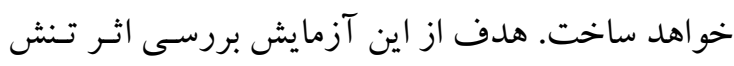

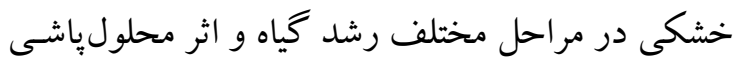

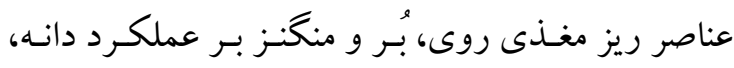

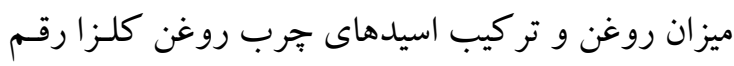

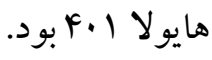

\section{مواد و روشها}

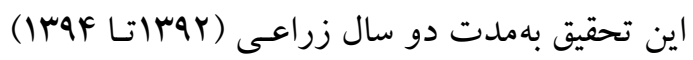

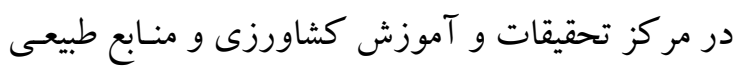

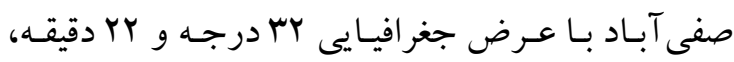

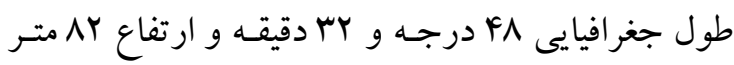

$$
\text { جدول 1- مشخصات تيمارهاى آبيارى و عناصر ريزمغذى }
$$

Table 1. Specifications of irrigation and micronutrients treatments

\begin{tabular}{|c|c|c|}
\hline $\begin{array}{c}\text { آبيارى كامل (شاهد 1) } \\
\text { Full irrigation }\left(\mathrm{S}_{1}\right)\end{array}$ & $\begin{array}{c}\text { قطع آبيارى در مرحله كلدهى (تنش شديد) } \\
\text { Irrigation withhold at flowering stage } \\
\text { (severe stress) }\left(S_{2}\right)\end{array}$ & $\begin{array}{c}\text { قطع آبيارى در مرحله خورجين دهى (تنش ملايم) } \\
\text { Irrigation withhold at silique formation stage } \\
\text { (mild stress) (S3) }\end{array}$ \\
\hline $\mathrm{Zn}_{1}: 2 \%$ & $\mathrm{Zn}_{2}: 4 \%$ & $\mathrm{Zn}_{3}: 6 \%$ \\
\hline $\mathrm{Mn}_{1}: 2 \%$ & $\mathrm{Mn}_{2}: 4 \%$ & $\mathrm{Mn}_{3}: 6 \%$ \\
\hline $\mathrm{B}_{1}: 2 \%$ & $\mathrm{~B}_{2}: 4 \% 0$ & $\mathrm{~B}_{3}: 6 \%$ \\
\hline محلول ياشى آب مقطر (شاهد Y) & & \\
\hline Distilled water (Control) & & \\
\hline
\end{tabular}

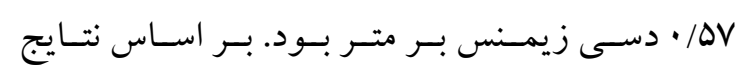

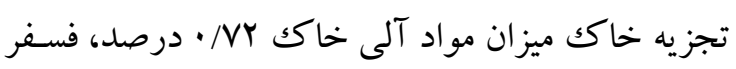

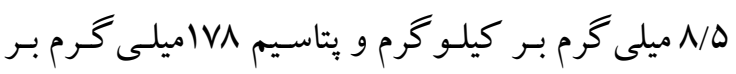

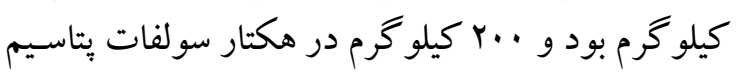

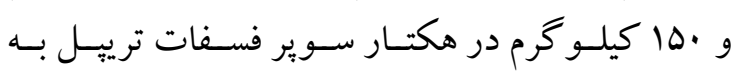

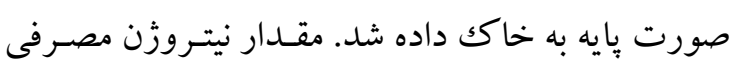

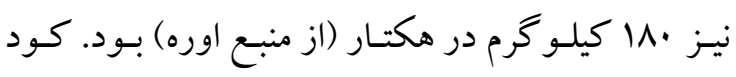

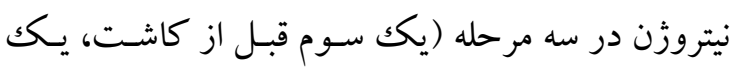

محلول ياشى بـا استفاده از سـمباش بشتسى كتـابى بـا

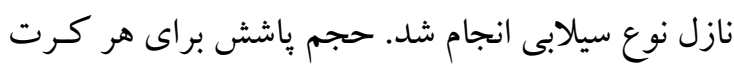

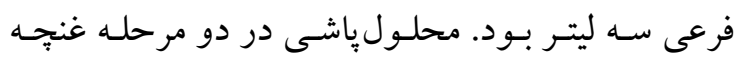

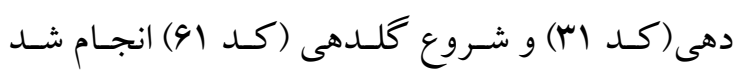
كانس (Sylvester-Bradley and Makepeace, 1984) كلـز زاى مــورد آزمــايش Hyola401 (شـــاهد منطقــه،

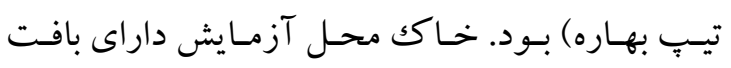

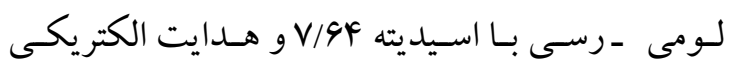


(تـــش ملايــم) و قطــع آبيــارى در مرحلـه كلــدهى

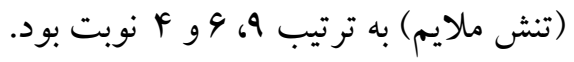

براى اندازه كيرى تعداد خورجين در بوته، تعداد دانه در خورجين و وزن هزار دانه، تعداد · ال بوته بـهصورت

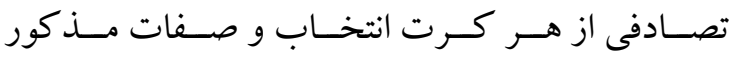

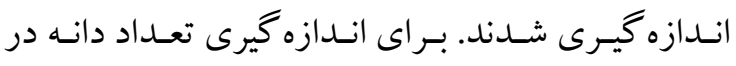
خورجين، · ․

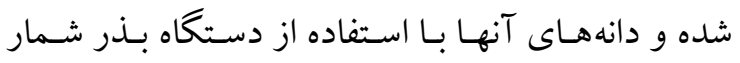
الكتريكى شمارش شده و بعد از ميـانكين گيـرى، تعـداد دانه در خورجين محاسـبه شـد. يـس از حسذف دو خـط

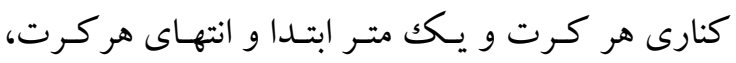
محصول F/A متر مربع از هر كـرت برداشت و عملكـرد

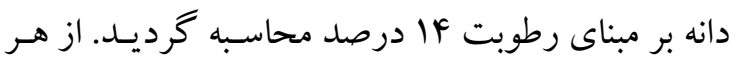

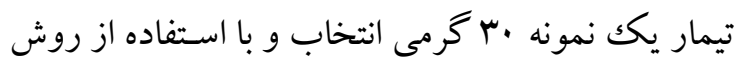
رزونانس مغناطيسى هسـته (NMR)، ميـزان روغـن دانسه اندازه كيرى شد. آماده سازى مشتق متيل استر اسـيدهاى

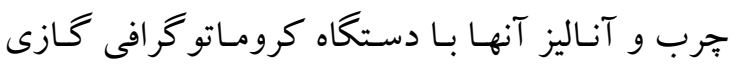
(GC-MS Varian 4000, Varian Inc. Netherlands) انجام گرفت (Azadmard-Damirchi and Dutta, 2008).

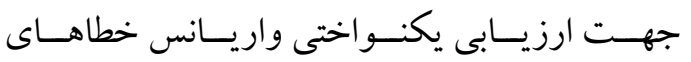

2013-14 Irar-ar

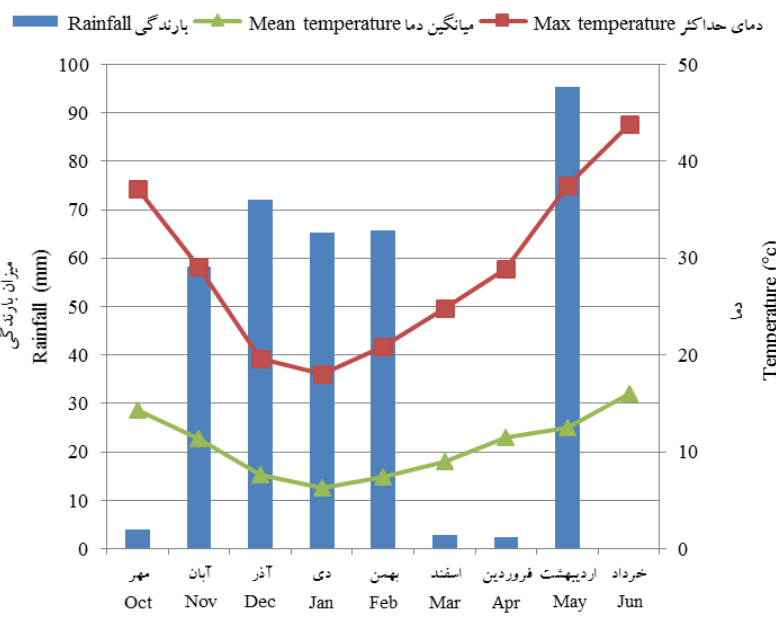

ماه هاى سال
سوم در مرحله ساقه رفتن و يكك سوم در اوايل كلدهى) بطور مساوى مصرف شد. زمين مزرعه آزمايشى در سال اول و قبل از زراعـت كلـزا، زيـر كشـت كنـدم بـود. در يايان سال اول آزمايش، در فصل تابستان، كياه مـاش در مزرعه كشت شده و يس از برداشت محصـول آن، سـال

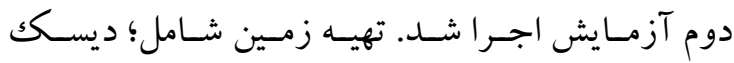

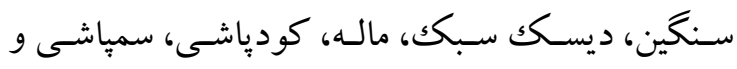
ديسـك سـبك (جهـت اخـتلاط كـود و علـف كش بـا خاكى) بود. قبل از كاشت بذر، علـف كـش تـرفلان بــ ميزان دو ليتردر هكتار به صورت خاكى مصـرف شـد و

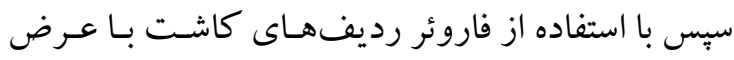
سانتيمتر ايجاد شدند. هر كـرت فرعى شـامل جهار

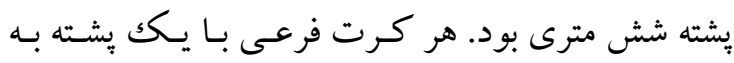
صورت نكاشـت از كـرت فرعى كنـارى جـدا كرديـد. آرايش كاشت به صورت دو رديف روى بپشته با تراكم

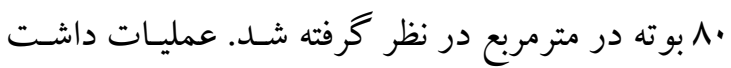
در طول فصل رشد بر حسب نيـاز انجـام كرفـت. ميـزان بارندكى و دما در طول دو سال آزمايش در شكل يـك ارائسه شـده اسـت. تعـداد دفعـات آبيـارى در تيمارهـاى آبيارى كامـل، قطـع آبيـارى در مرحله خـورجيندهى

2014-15 Irar-qF

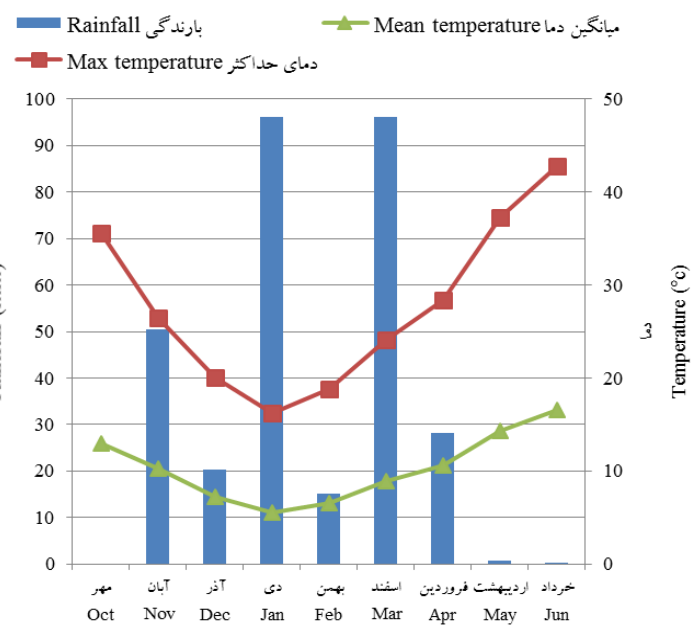

ماه هاى سال

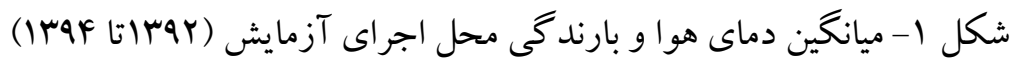

Fig. 1. Mean of temperature and rainfall at experiment site (2013-2015) 


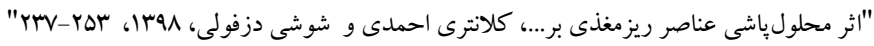

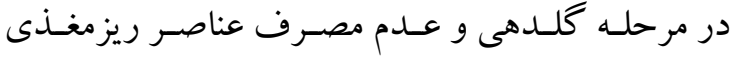
(محلول ياشى با آب مقطر) بـود (شـكل Y). بـر اسـاس نتايج مربوط به اثر مقابل تيمارهـاى آزمايشـى بـر تعـداد خورجين در بوتسه بـه نظـر مسىرسـد كه مرحله كلـدهى حساسترين مرحله به تنش خشكى بوده و باعث كاهش تعـداد خــورجين در بوتسه مسى شـود. تسنش در مرحلـه ساقهدهى و كلدهى بدليل عرضه كمتر مـواد فتوسـنتزى، باعث ريزش كل و خورجينهاى در حال رشد در كلز ا مسىشـود (Robertson and Holland, 2004). تعـداد

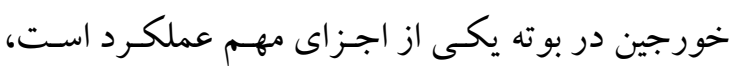
زيرا خورجينها در بر گيرنده دانهها، توليـد كنتـده مـواد فتوسنتزى مـورد نيـاز دانـههـا و نيـز ذخيـره كنتـده مـواد جـذب شـده و سـنتز شــده در بـر كَهـا بـوده كـه ايسن مواد از ديواره خورجين به دانسها منتقـل شـده و باعـث نمو دانهها مىشـوند، بنـابراين خـورجين هـا تـا حسدودى معيارى براى بيشبينـى وزن دانسهــا محسـوب مىشـوند

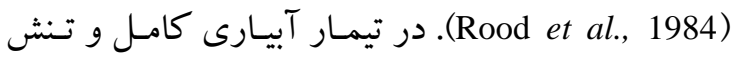
ملايم (قطع آبيـارى در مرحله خـورجين دهى) تعـداد

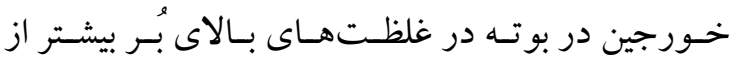

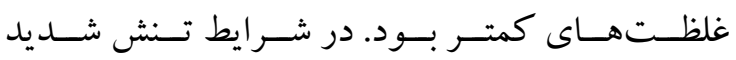

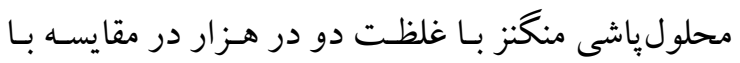
ساير تيمارهاى محلولياشى، بيشـترين تـاثير رابـر تعـداد
آزمايشـى آزمـون بارتلـت انجـام كرفت و نتـايج كـاى

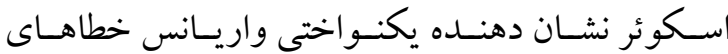
آزمايشى در دو سال بود. تجزيه آمارى با استفاده از نـرم افزار SAS نسـخه و و مقايسـه ميـانكين هـا بـا استفاده از روش تــوكى در ســح احتمــال يــنج درصـــ و رســم نمودارها با استفاده از نرم افزار Excel انجام كرفت.

\section{نتايج و بحث}

نتايج تجزيه واريانس مركب دادهها نشان داد كه اثـر سال، آبيارى، محلولياشى، سـال × آيـارى و آبيـارى × محلول ياشى بر تعـداد خـورجين در بوتـه معنسىدار بـود. قطع آبيـارى در مرحلـه كلـدهى كـاهش شــديد تعـداد خورجين در بوته را بهدنبال داشـت. مقايسـه ميـانگينهـا

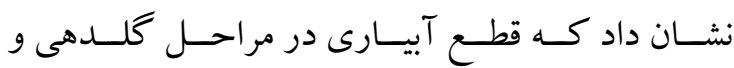
خـورجين دهـى تعـداد خـورجين در بوتسه را بـه ترتيـب

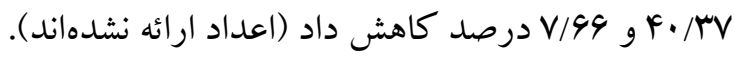
برهمكنش آبيـارى × محلـول ياشى نيـز باعـث كـاهش شديد تعداد خورجين در بوته در تيمار قطع آبيـارى در

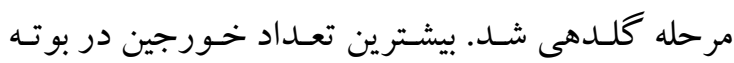

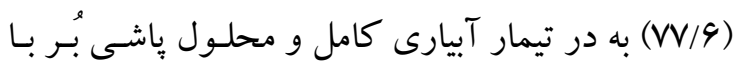
غلظـت شـش در هـز ار بدسـت آمـد. كمتـرين تعـداد خورجين در بوته (سM) نيز مربوط به تيمـار قطع آبيـارى

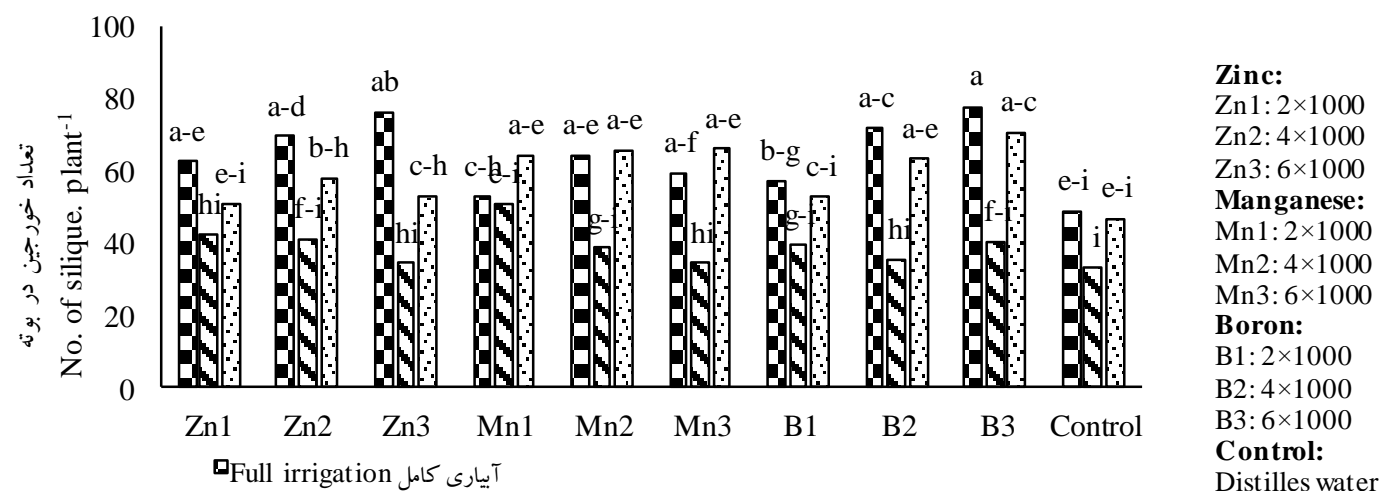

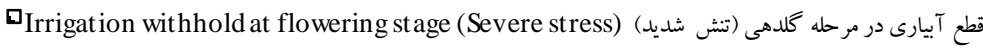

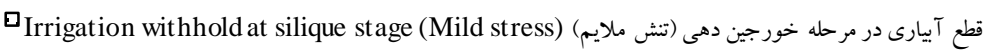

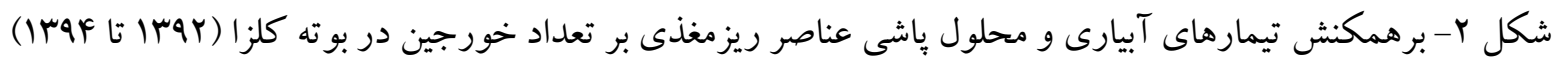

Fig. 2. Interaction effect of irrigation and foliar application of micro nutrient treatments on number of silique.plant ${ }^{-1}$ in canola (2013-2015) 


$$
\text { "نشريه علوم زراعى ايران"، جلد بيست و يكم، شماره "ا، باييز شجسا }
$$

آنزيمهاى مو جود در مسـيرهاى متابوليكك تبـديل مـواد فتوسنتزى به انرزى و اجزاى عملكرد اثر مثبـت داشـته و

$$
\text { باعث افزايش محصول كياه مىشود. }
$$

نتايج تجزيه واريانس مركب دادهها نشان داد كه اثر

سال، آبيارى و محلول ياشى و همجنين برهمكنش سـال

× آبيـارى بـر تعـداد دانسه در خـورجين معنسىدار بـود.

مقايسه ميانگينها نشان داد كه تعـداد دانسه در خـورجين در سال اول و دوم آزمايش به ترتيب ه/ (اعداد ارائه نشدهاند). افزايش شدت تنش خشكى باعث كاهش تعداد دانه در خـورجين شـد (شـكل ب). مقايسـه ميانكين ها نشان داد كـه بيشـترين (ه/هـ) تعـداد دانـه در خورجين در سال دوم در تيمار آبيارى كامل و كمتـرين
خورجين در بو ته داشت. در شرايط مطلوب رطوبتى نيـز محلولياشى روى با غلظت شش در هزار با محلولياشى بُر با غلظت شش در هـزار در يـك گَّروه آمـارى قـرار

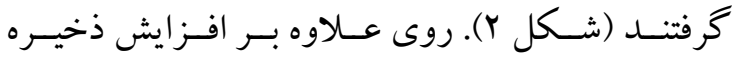
كربوهيدراتهاى دانه در سنتز يـروتئين لوله كـرده نيـز سهيم بوده و باعث ذخيره يروتئين شده كه اين موضسوع باعث افزايش كرده افشانى، تشكيل ميـوه و دانسه بيشـتر مىشود (Marschner, 1995). وجود عناصـر ريـز مغـذى نظير روى در مناطق مريستمى، بعلت نقـش آن در توليـد هورمسون اكسـين باعـث افززايش شـاخه بنــى و تعـداد خـورجين در بوتسه مسىشـود (Tandon, 2005). بـه نظـر مىرسد كه محلول ياشى عناصر ريزمغذى بر فتوسـنتز و

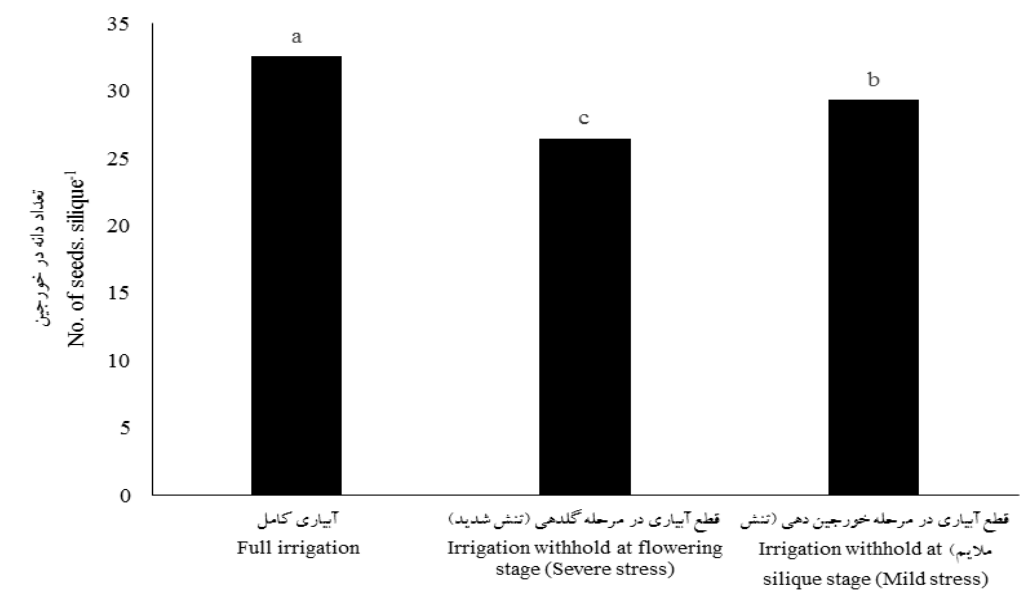

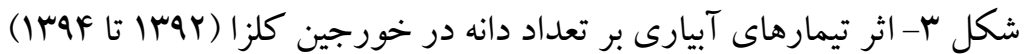

Fig. 3. Effect of irrigation treatments on number of seed.silique ${ }^{-1}$ in canola (2013-2015)

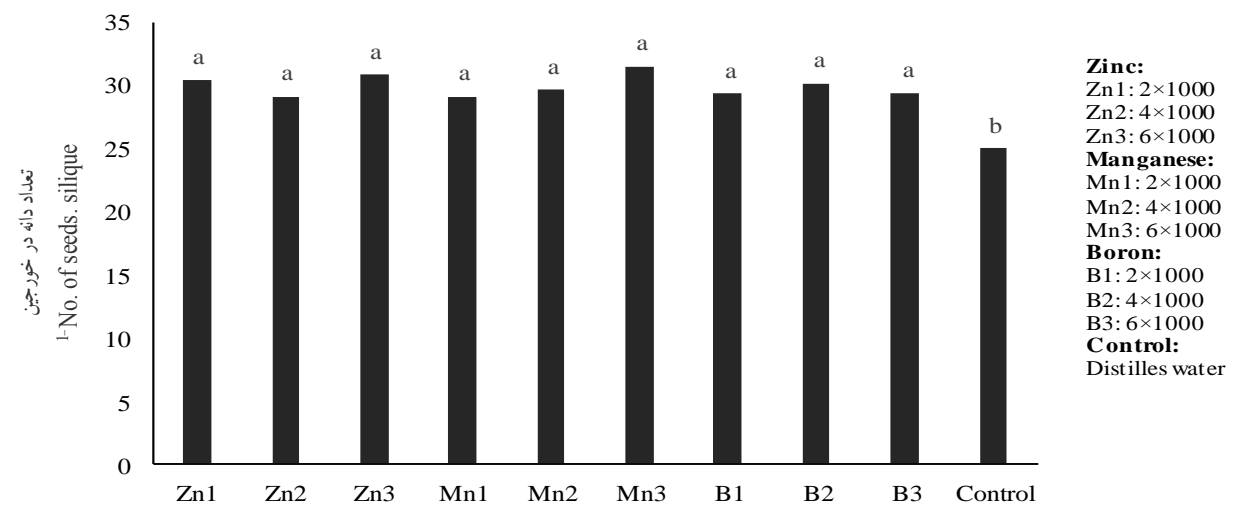

شكل F- اثر تيمارهاى محلولياشى عناصر ريزمغذى بر تعداد دانه در خورجين كلزا (YM تا تا FqM)

Fig. 4. Effect of foliar application of micro nutrients treatments on number of seed.silique ${ }^{-1}$ in canola (2013-2015) 
اول در تيمـار قطع آبيـارى در مرحلـه كلـدهى بدسـت

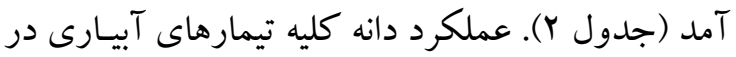

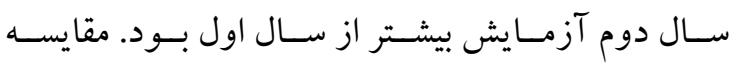

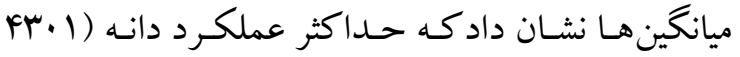

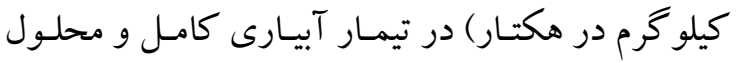

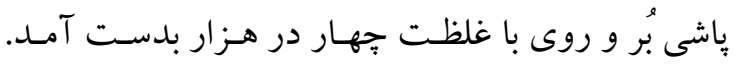

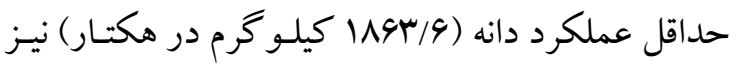

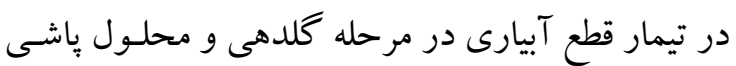

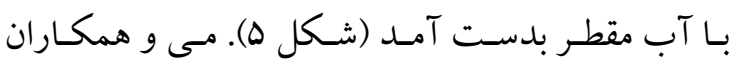

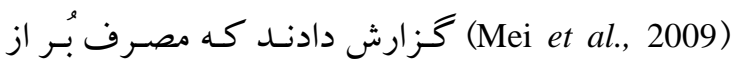
طريق افزايش تعداد خورجين در بوتهه و تعـداد دانهه در

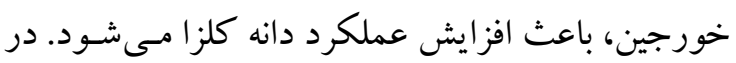

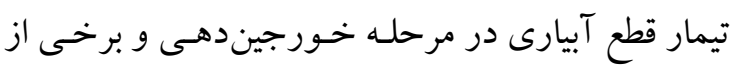

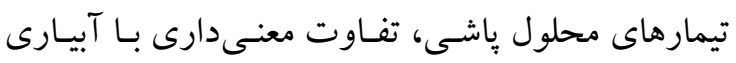

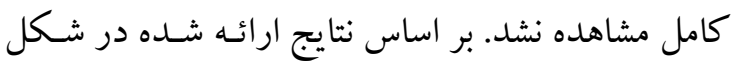

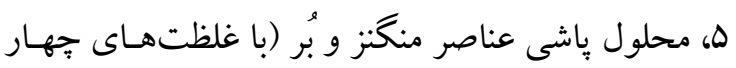

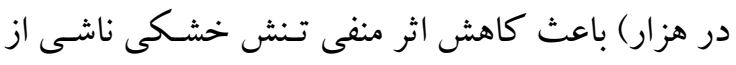

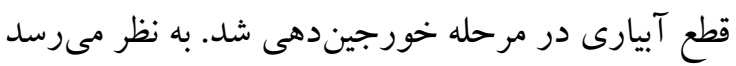

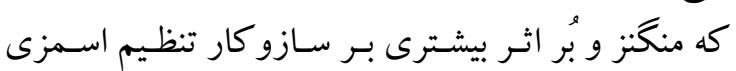

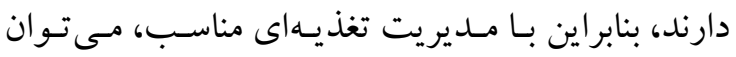

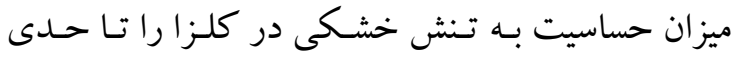

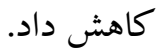
نتايج تجزيـه واريـانس نشـان داد كـه اثر تيمارهـاى داد آبيارى و محلول بِاشى بر وزن هزار دانه كلـزا معنسىدار

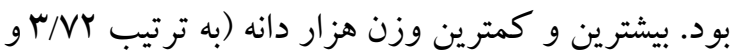

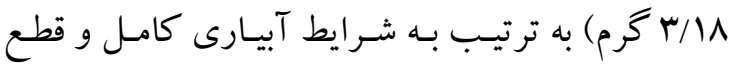
آبيارى در مرحله كلدهى بدست آمـد (شـكل 9). تسنش

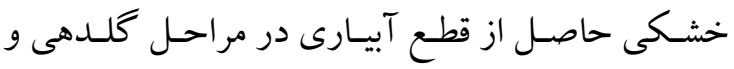

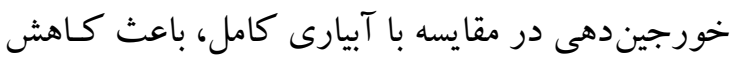

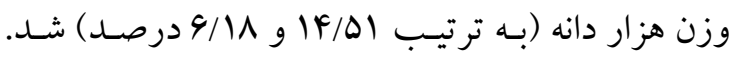

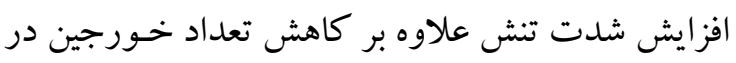

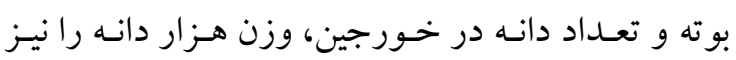

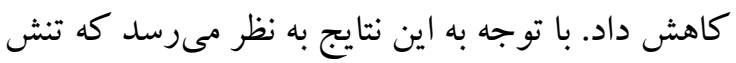

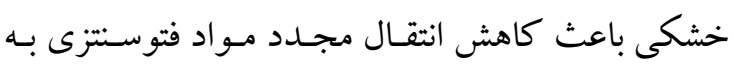

تعداد دانه در خورجين نيز در سال اول در تيمار (YF/A)

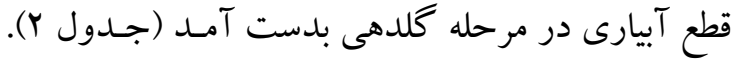
كاهش تعداد دانه در خورجين در تيمار قطع آبيـارى در

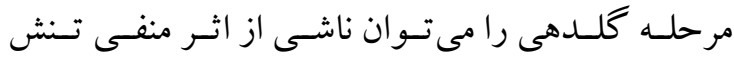

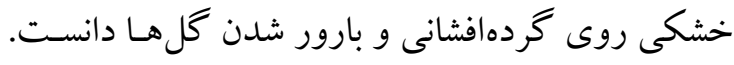

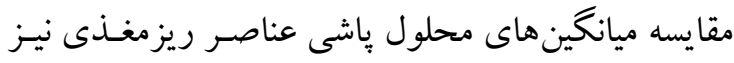
نشان داد كه كليه تيمارهاى محلول بِاشى در يكى گحروه

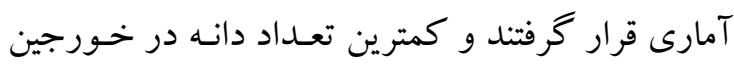

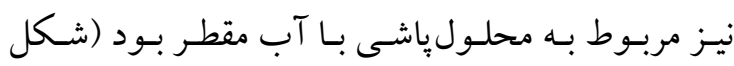

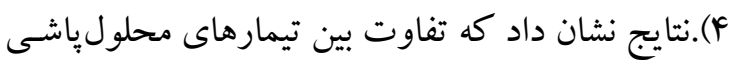

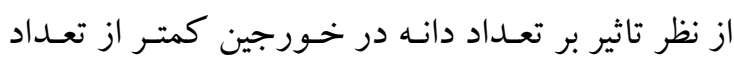

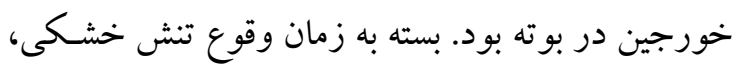

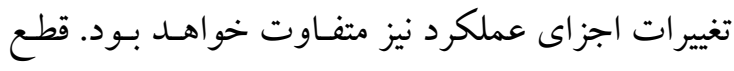

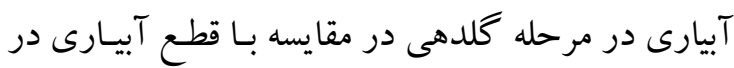
مرحله خورجين دهى تعـداد دانه در خـورجين را بيشـتر

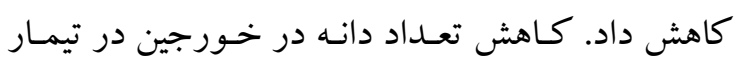

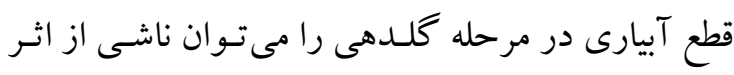

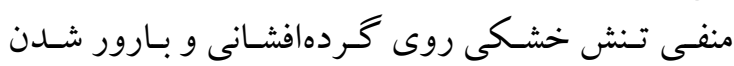
كل ها دانست. عوامل تنش زايى كه در اوايل فصل رشد رود

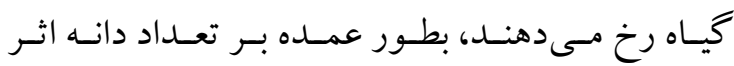

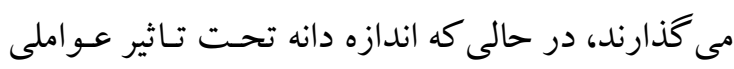

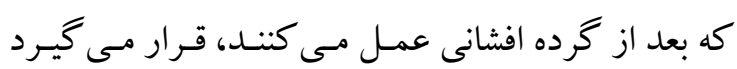
(Kimber and Mc Gregor, 1995) (تغييرات در رشـــ

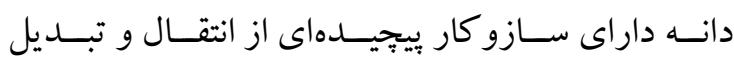

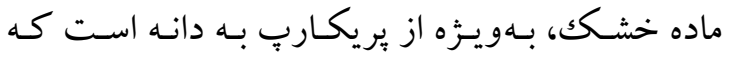

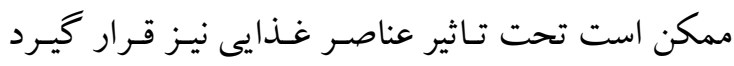

.(Mei et al., 2009) نتايج تجزيه واريانس مر كب دادهها نشان داد كه اثر سال، آبيارى و محلول بِاشى بـر عملكـرد دانه معنى دار

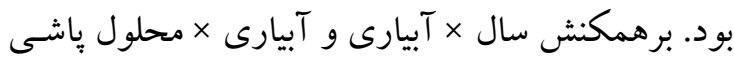

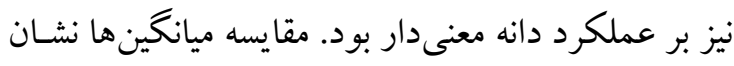

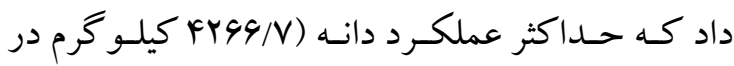

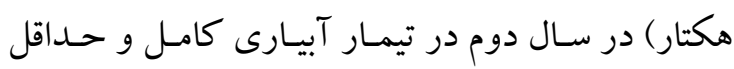

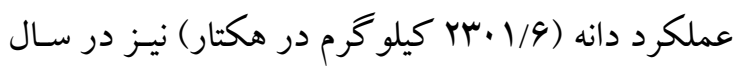




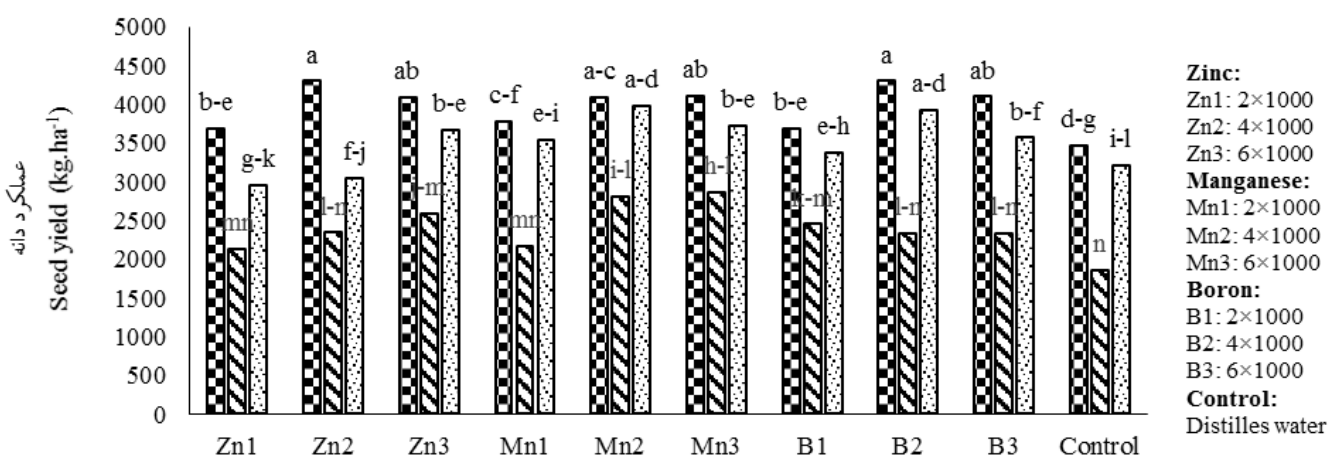

Full irrigation Tكارى كار

ه تطع آيبارى در مرحله كلدهى (تنش شديد)

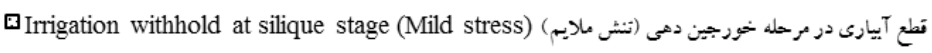

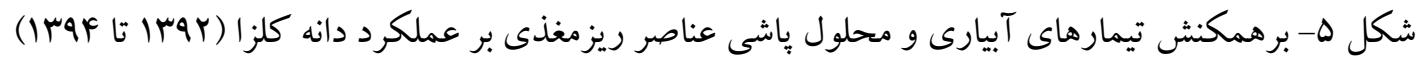

Fig. 5. Interaction effect of irrigation and foliar application of micro nutrient treatments on seed yield of canola (2013-2015)

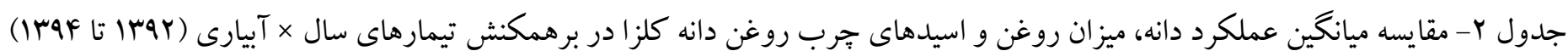

Table 2. Mean comparison of seed yield, oil content of seed and fatty acids content of seed oil of canola in interaction effect of year $\times$ irrigation treatments (2013-2015)

\begin{tabular}{|c|c|c|c|c|c|c|c|}
\hline \multicolumn{2}{|c|}{ تيمارهاى آزمايشى Treatments } & \multirow[b]{2}{*}{$\begin{array}{c}\text { عملكرد دانه } \\
\text { Seed yield } \\
\left(\text { kg.ha }{ }^{-1}\right)\end{array}$} & \multirow{2}{*}{$\begin{array}{c}\text { روغن دانه } \\
\text { Oil content } \\
\text { of seed } \\
(\%)\end{array}$} & \multirow[b]{2}{*}{$\begin{array}{c}\text { اسيد لينولئيك } \\
\text { Linoleic acid } \\
\text { (\%) }\end{array}$} & \multirow[b]{2}{*}{$\begin{array}{c}\text { اسيد يالميتيك } \\
\text { Palmitic acid } \\
(\%)\end{array}$} & \multirow[b]{2}{*}{$\begin{array}{c}\text { اسيد استئاريكك } \\
\text { Stearic acid } \\
\text { (\%) }\end{array}$} & \multirow[b]{2}{*}{$\begin{array}{c}\text { اسيد اولئيك } \\
\text { Oleic acic } \\
\text { (\%) }\end{array}$} \\
\hline $\begin{array}{c}\text { سال × آبيارى } \\
\text { Yearrigation }\end{array}$ & $\begin{array}{c}\text { تعداد دانه در خورجين } \\
\text { No. of grain. silique }\end{array}$ & & & & & & \\
\hline \multirow{3}{*}{$\begin{array}{l}\text { Irar-qr } \\
2013-14\end{array}$} & $29.5 c$ & $3612.8 b$ & $44.1 \mathrm{a}$ & $21.81 \mathrm{~b}$ & $3.61 \mathrm{~b}$ & $1.73 \mathrm{~b}$ & $54.61 \mathrm{a}$ \\
\hline & $24.8 \mathrm{e}$ & $2301.6 \mathrm{~d}$ & $41.6 \mathrm{c}$ & $15.27 \mathrm{f}$ & $2.54 \mathrm{f}$ & $1.15 \mathrm{~d}$ & $38.38 \mathrm{c}$ \\
\hline & $26.3 \mathrm{de}$ & $3142.8 \mathrm{c}$ & $42.8 b$ & $18.03 \mathrm{~d}$ & $3.13 \mathrm{~d}$ & $1.45 \mathrm{c}$ & $46.51 \mathrm{~b}$ \\
\hline \multirow{3}{*}{$\begin{array}{l}\text { Irqr_qf } \\
2014-15\end{array}$} & $35.5 \mathrm{a}$ & $4266.7 \mathrm{a}$ & $44.2 \mathrm{a}$ & $24.49 \mathrm{a}$ & $3.88 \mathrm{a}$ & $1.94 \mathrm{a}$ & $54.91 \mathrm{a}$ \\
\hline & $28.0 \mathrm{~cd}$ & $2476.0 \mathrm{~d}$ & $40.9 \mathrm{~d}$ & $17.50 \mathrm{e}$ & $2.69 \mathrm{e}$ & $1.11 \mathrm{~d}$ & $38.36 \mathrm{c}$ \\
\hline & $32.2 \mathrm{~b}$ & $3701.5 b$ & $42.5 b$ & $19.03 d$ & $3.25 c$ & $1.39 \mathrm{c}$ & $45.89 \mathrm{~b}$ \\
\hline 1 irrigation & ) & & & & & شن شديد) & إمل در مرحله \\
\hline
\end{tabular}

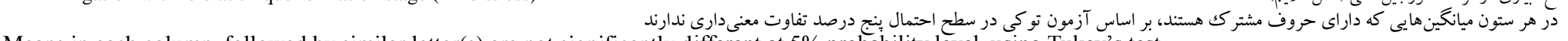




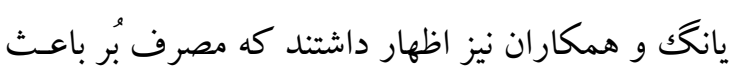

افزايش وزن هـزار دانهه مسىشود (Yang et al., 2009).

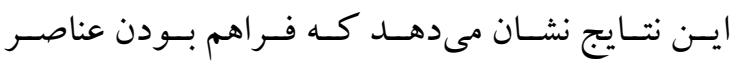

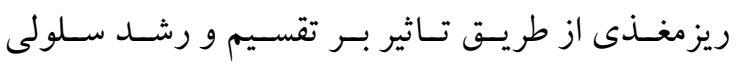

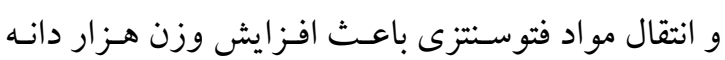

$$
\text { مىشود. }
$$

نتايج تجزيه واريانس مركـب دادهـــا نشـان داد كـه اثر

سال، آبيارى، محلول پاشى، سال × آبيـارى و آبيـارى ×

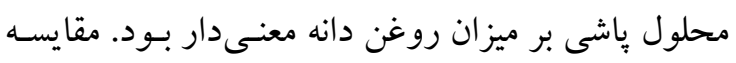

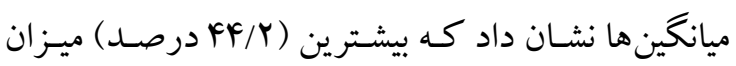

دانه شد. بيشترين (Y/V4

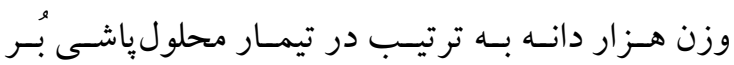

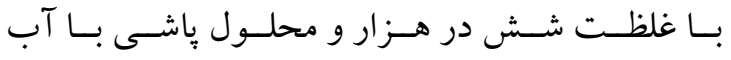

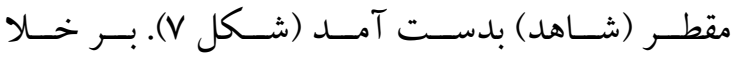

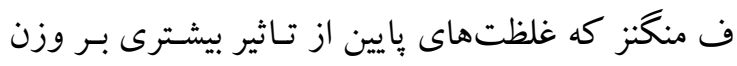

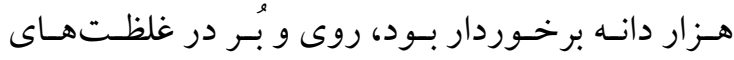

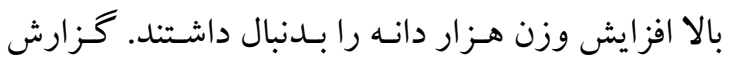

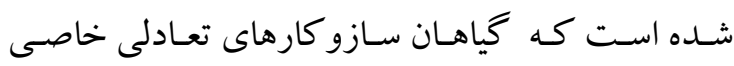

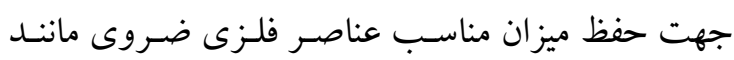
مس و منغنـز دارنــ (Krupa and Baszynski, 1995).

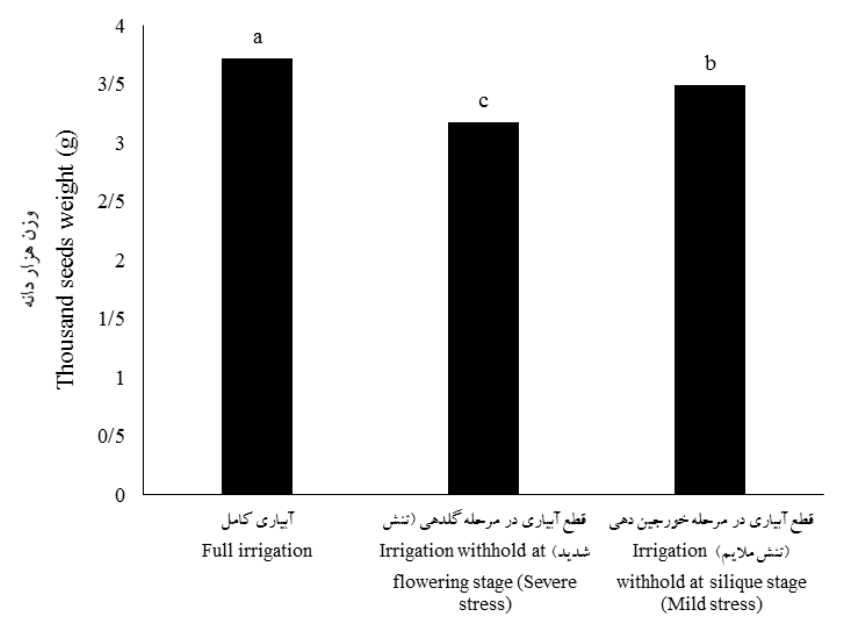

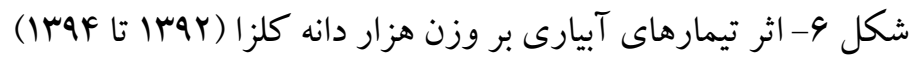

Fig. 6. Effect of irrigation treatments on thousand seeds weight in canola (2013-2015)

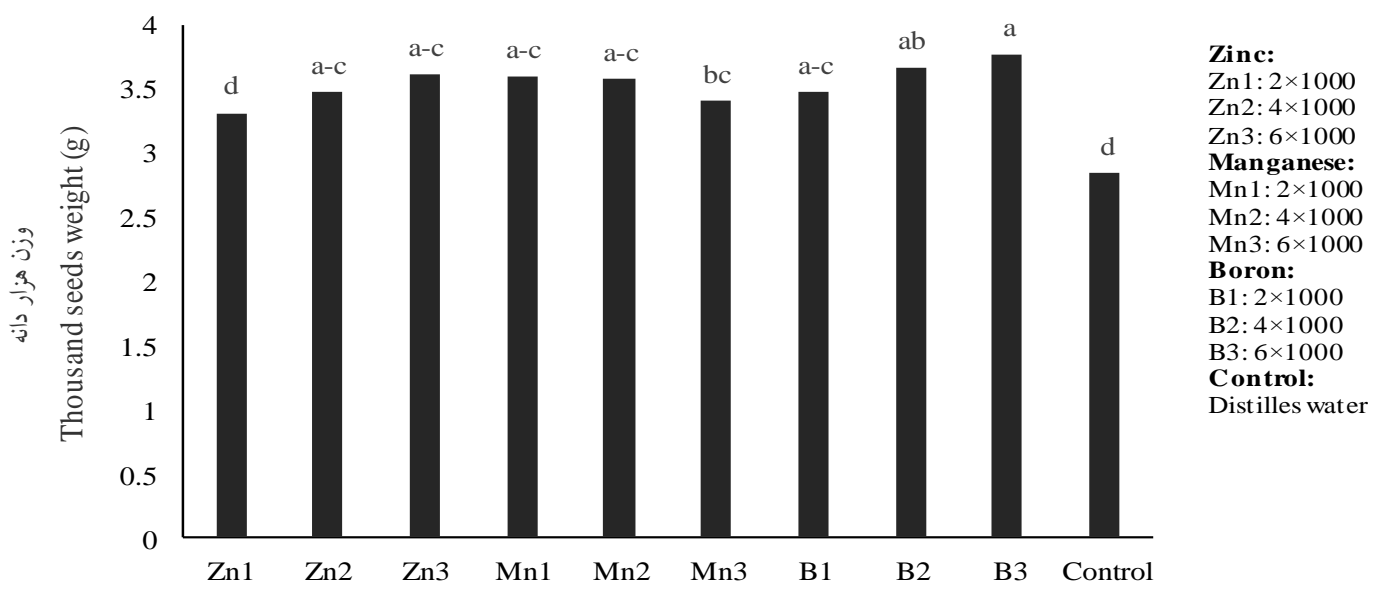

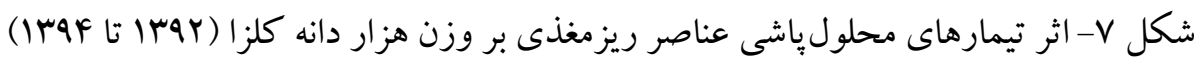

Fig. 7. Effect of foliar application of micro nutrients treatments on thousand seeds weight in canola (2013-2015) 


$$
\text { "نشريه علوم زراعى ايران"، جلد بيست و يكم، شماره "ا، باييز شهسا }
$$

باعـث افـزايش ميـز ان روغـن دانسه شـود، امــا تــش خشكى در مرحله كلدهى، باعث كاهش ميـزان روغن

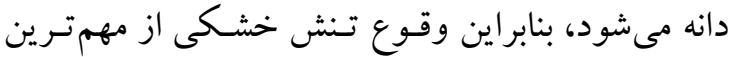

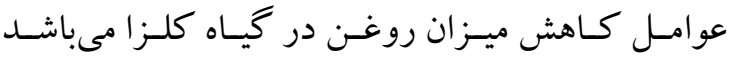

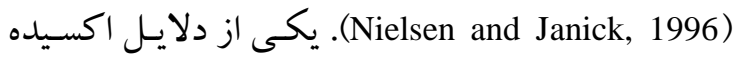
شدن سريع روغن كلزا، بالا بودن ميزان اسيدهاى جـرب غير اشباع روغن دانه است و با وقوع تنش خشـكى، ايسن موضوع نيز تشديد مى شود (Kosaki et al., 2002). نتايج

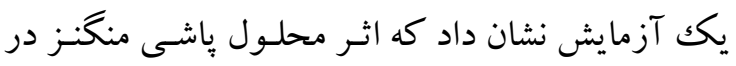
شرايط مختلف رطوبتى بـر ميـزان روغن دانسه كلرنـــ بسيار اندك بود (Movahhedy-Dehnavy et al., 2009)،

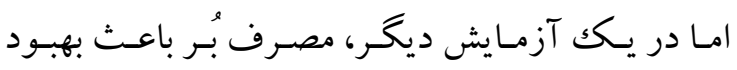
كيفيت روغن كلزا شد (Yang et al., 2009).

$$
\begin{aligned}
& \text { روغن در سال اول در تيمار آبيارى كامـل بدسـت آمــد. } \\
& \text { كمترين (q/9 ع درصد) ميزان روغـن نيـز در تيمـار قطع } \\
& \text { آبيـارى در مرحلـه كلــدهى و در سـال دوم آزمـايش } \\
& \text { بدست آمد (جدول Y). مقايسه ميانكينها نشـان داد كـه } \\
& \text { بيشترين ميزان روغن (FD/9 درصـد) در شـرايط آبيـارى } \\
& \text { كامل و محلول ياشى روى و بُر با غلظـت شـش درهـزار } \\
& \text { بدست آمد. كمترين ميزان روغن (س/.F درصد) نيـز در }
\end{aligned}
$$

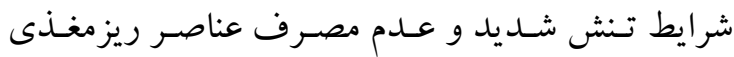

$$
\begin{aligned}
& \text { بدست آمد (شكل ^). تنش خشكى باعـث بسـته شـدن }
\end{aligned}
$$

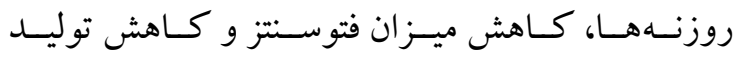

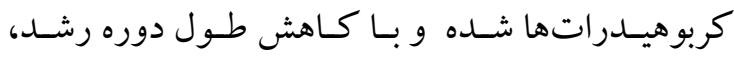

$$
\begin{aligned}
& \text { فرصت كافى براى سنتز روغن وجود نداشته و در نتيجـه }
\end{aligned}
$$

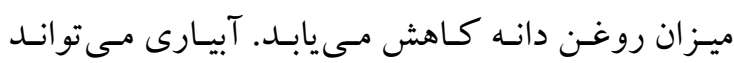

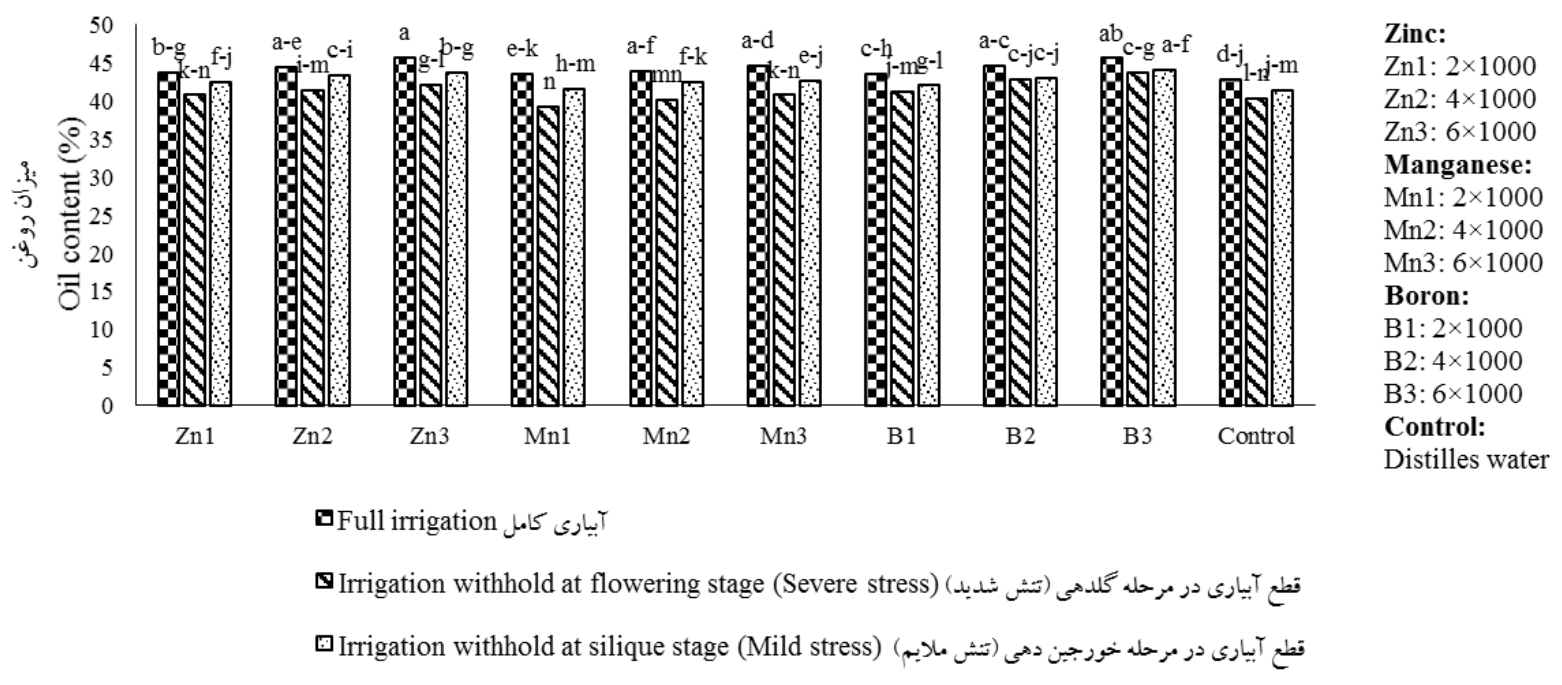

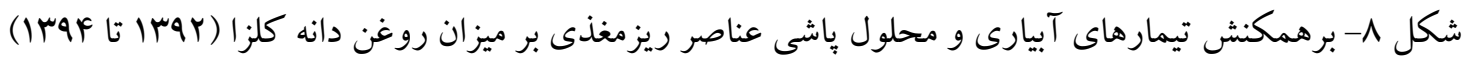

Fig. 8. Interaction effect of irrigation and foliar application of micro nutrient treatments on oil content of seed of canola (2013-2015

و در سال اول و تيمـار قطع آيـارى در مرحله كلـدهى بدسـت آمـد. ميـزان اسـيد يالميتيـك در هـر دو سـال در تيمـار قطـع آبيـارى در مرحلـه كلــدهى از سـاير تيمارهاى آبيارى كمتر بود (جدول Y). بـه نظـر مىرســ

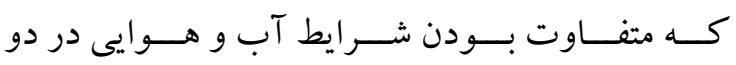
سـال آزمــايش (شـكل r) باعـث تفــاوت در ميـزان
نتايج تجزيه واريانس مركب نشان داد كه اثر سـال، آبيـارى، محلـول پاشـى، سـال × آبيـارى و آبيـارى × محلولياشى بر ميزان اسيد يالميتيك روغن دانه معنى دار

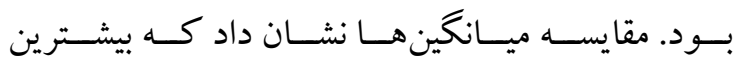

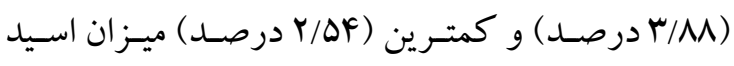
يالميتيكك به ترتيب در سـال دوم و تيمـار آبيـارى كامـل 


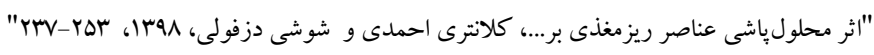

(نيز در شرايط تنش شديد و عدم استفاده (T/Y)

از عناصر ريزمغذى مشاهده شـد. مصسرف ريزمغـذىهـا هـم در شـرايط آبيـارى كامـل و هــم در شــرايط تسنش

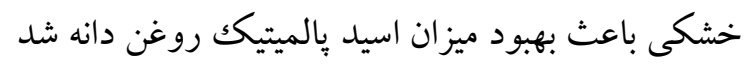

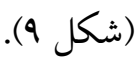

اسيد يالمتيكك شده است. مقايسه ميانگينها نشان داد كه تنش خشكى باعث كاهش ميـزان اسـيد بالميتيـك شـد. بيشـترين ميـز ان اسـيد بالميتيـك (F) (F درصـد) در تيمـار آبيارى كامل و محلولياشى بُر (با غلظت شش در هزار)

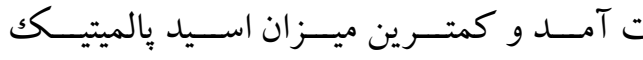

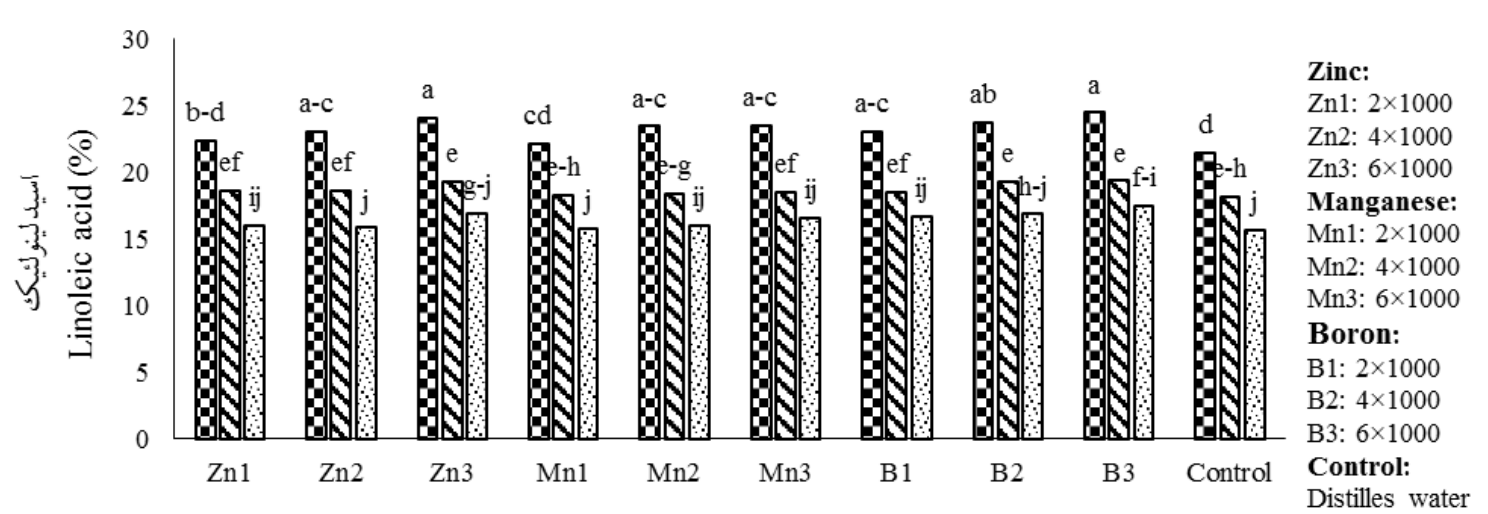

ت Tull irrigation بيارى كامل

ه تطع آبيارى در مرحلد گلدهى (تنش شدبد) (Srrigation withhold at flowering stage (Severe stress)

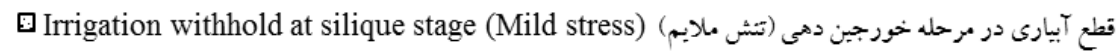

شكل 9- برهمكنش تيمارهاى آبيارى و محلول ياشى عناصر ريزمغذى بر ميز ان اسيد لينولئك روغن دانه كلزا

(Irqf إ)

Fig. 9. Interaction effect of irrigation and foliar application of micro nutrient treatments on palmitic acid content of seed of canola (2013-2015)

بود. بهنظر مىرسـد كـه بـالاتر بـودن دمـاى ارديبهشـت

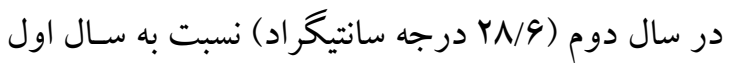

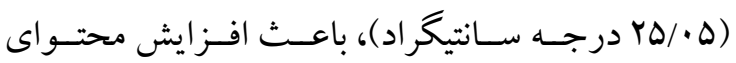
اسيد استئاريكك روغن در تيمار آبيارى شـد، لـيكن اثر

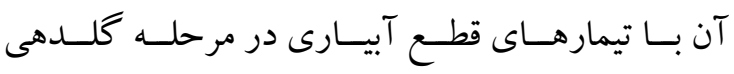

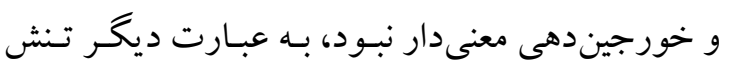

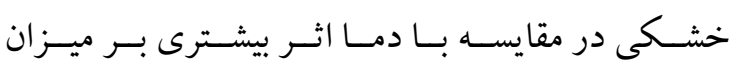
اسيد استئاريكك داشـته اسـت. مقايسـه ميـانكين هـا نشـان داد كه محلول ياشى عناصر ريزمغذى نيز باعث افزايش

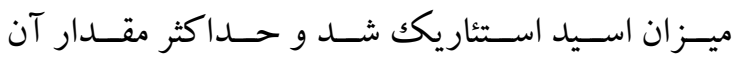

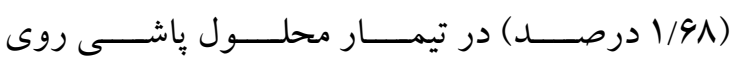
(شش در هزار) مشاهده شد. افزايش غلظت منگخنز و بُّر نيز باعث افزايش ميز ان اسيد اسـتئاريكك كرديــ (شـكل

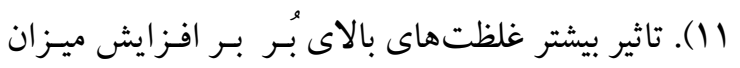

$$
\begin{aligned}
& \text { نتـايج تجزيـهـ واريـانس مركـب نشـان داد كـهـ اثــر } \\
& \text { آبيارى، محلول بِاشى و بــرهمكنش سـال × آبيـارى بـر }
\end{aligned}
$$

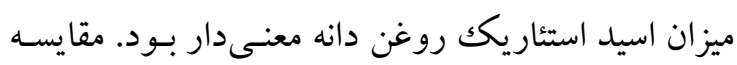

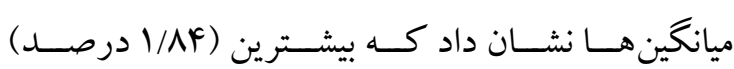

$$
\begin{aligned}
& \text { و كمتـرين (س// درصـد) ميـز ان اسـيد اسـتئاريكك بـه } \\
& \text { ترتيب به در تيمارهاى آبيارى كامـل و قطع آبيـارى در }
\end{aligned}
$$

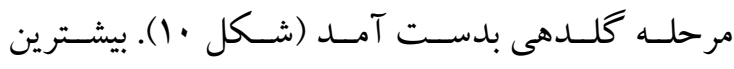

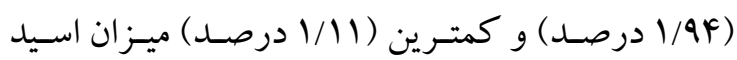

$$
\begin{aligned}
& \text { استئاريكك در سال دوم به ترتيـب در تيمارهـاى آبيـارى }
\end{aligned}
$$

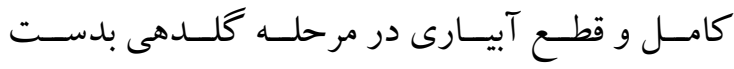

$$
\begin{aligned}
& \text { آمد (جدول Y). نتايج نشان داد كه تفاوت شرايط آب و } \\
& \text { هـوايى در دو سـال آزمـايش (شـكل () فقـط در تيمـار } \\
& \text { آبيارى كامل اثر معنى دارى داشت، به ترتيبى كـه ميـزان } \\
& \text { اسيد استئاريكك روغـن در سـال دوم بيشـتر از سـال اول }
\end{aligned}
$$




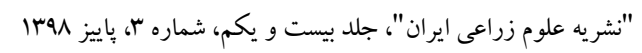

$$
\begin{aligned}
& \text { عنصر در مقايسه با ساير ريز مغذىها جهت افزايش اين } \\
& \text { اسيد پِالميتيك (شكل 9) و اسيد استئاريكك (شكل (1) } \\
& \text { اسيدهاى جرب غير اشباع باشد. }
\end{aligned}
$$

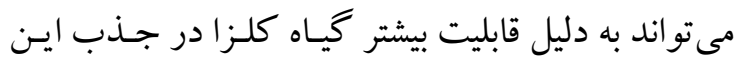

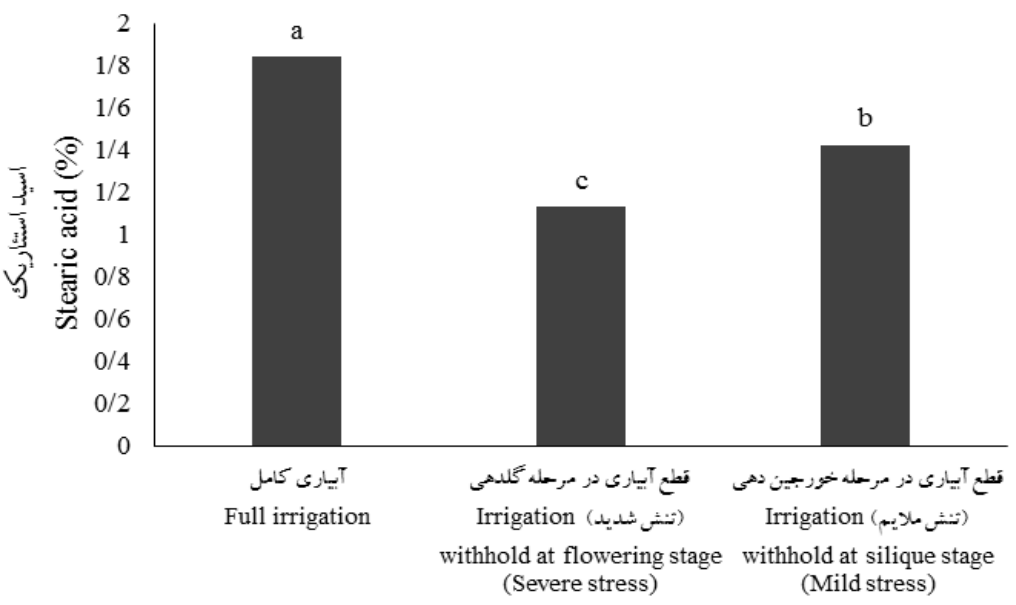

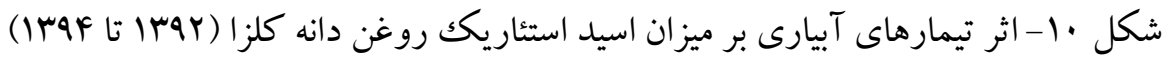

Fig. 10. Effect of irrigation treatments on stearic acid content of seed of canola (2013-2015)

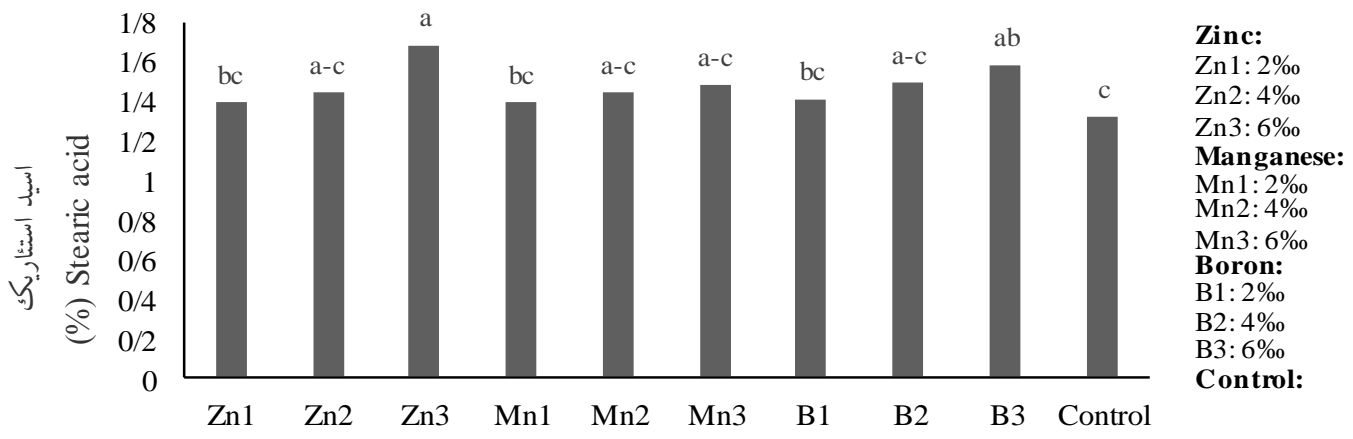

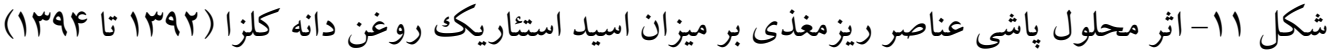

Fig. 11. Effect of foliar application of micro nutrient treatments on stearic acid content of seed of canola (2013-2015)

ميانگين ها نشان داد كه اعمال تنش خشكى ناشى از قطع

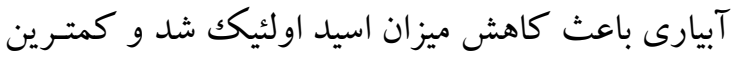

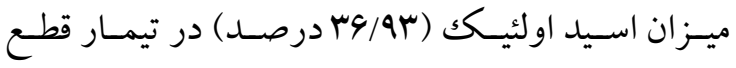
آبيـارى در مر حلـه گلــدهى و عـدم اسـتفاده از عناصـر

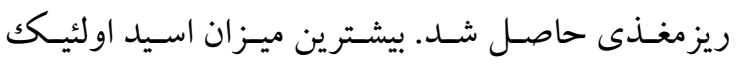

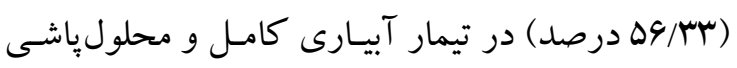

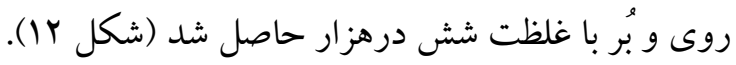

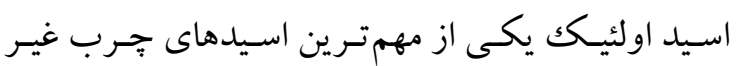

$$
\begin{aligned}
& \text { نتايج نشان داد كه اثر سال، آبيارى، محلـولياشى و } \\
& \text { همجيخــين بــرهمكنش ســال × آبيــارى و آبيــارى × }
\end{aligned}
$$

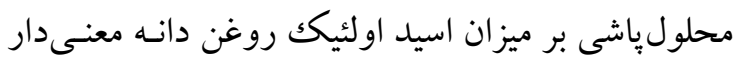

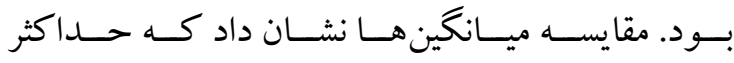

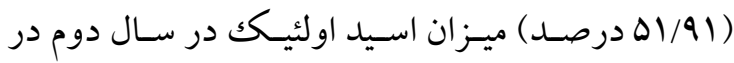

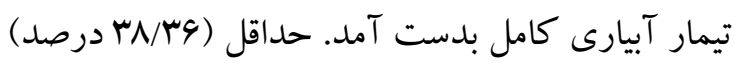

$$
\begin{aligned}
& \text { ميزان اسيد اولئيك نيز در سال دوم و تيمار قطع آبيـارى لئم }
\end{aligned}
$$

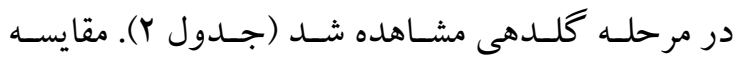




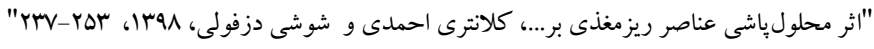

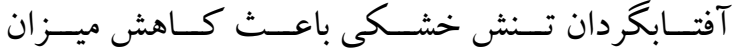
اسيد اوليكك كرديد (Baldini et al., 2002). اثر محلول باشى بُر و روى در افزايش ميزان اسـيد اولئيكك هـم در

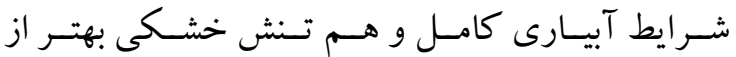

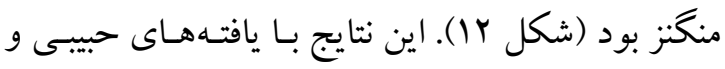
همكـاران (Habibi et al., 2014) مبنـى بـر اثـر مثبـت

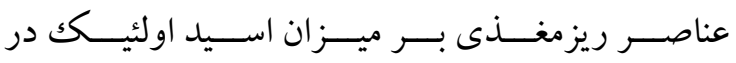
شـرايط رطـوبتى مطلـوبـ مطابقــت دارد. بــا توجـهـ بـــ

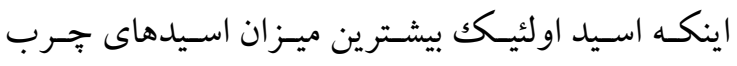

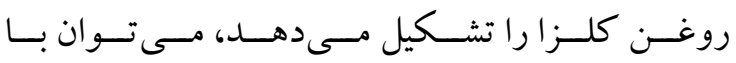
مديريت تغذيهاى مناسب، كيفيـت روغـن دانسه كلـزا را

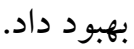

اشباع كلزا است و بر اساس نتايج بدست آمده مسىتوان دليـل كـاهش اسـيد اولئكك در تيمـار قطع آبيـارى در

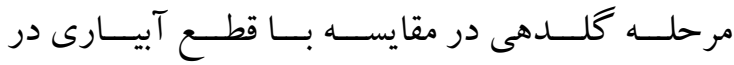
مرحله خورجين دهى را به افزايش ميزان اسيد لينولئك

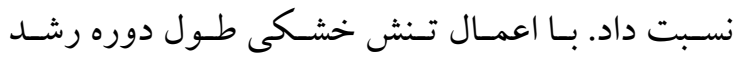
و ظرفيـت مخــزن كــاهش يافتـهـ و زمــان لازم بــــاى

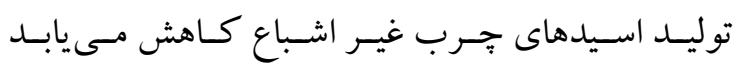
(Moghadam et al., 2011) اسـيد اولئيـكك در شــرايط تــش خشـكى خزارشـات متفــاوتى وجـود دارد. بـر اسـاس نتـايج يـكك آزمـايش تــش خشـكى اثــى بــر ميـزان اســيد اولئيـك ارقـام

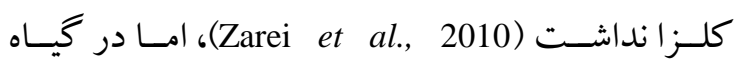

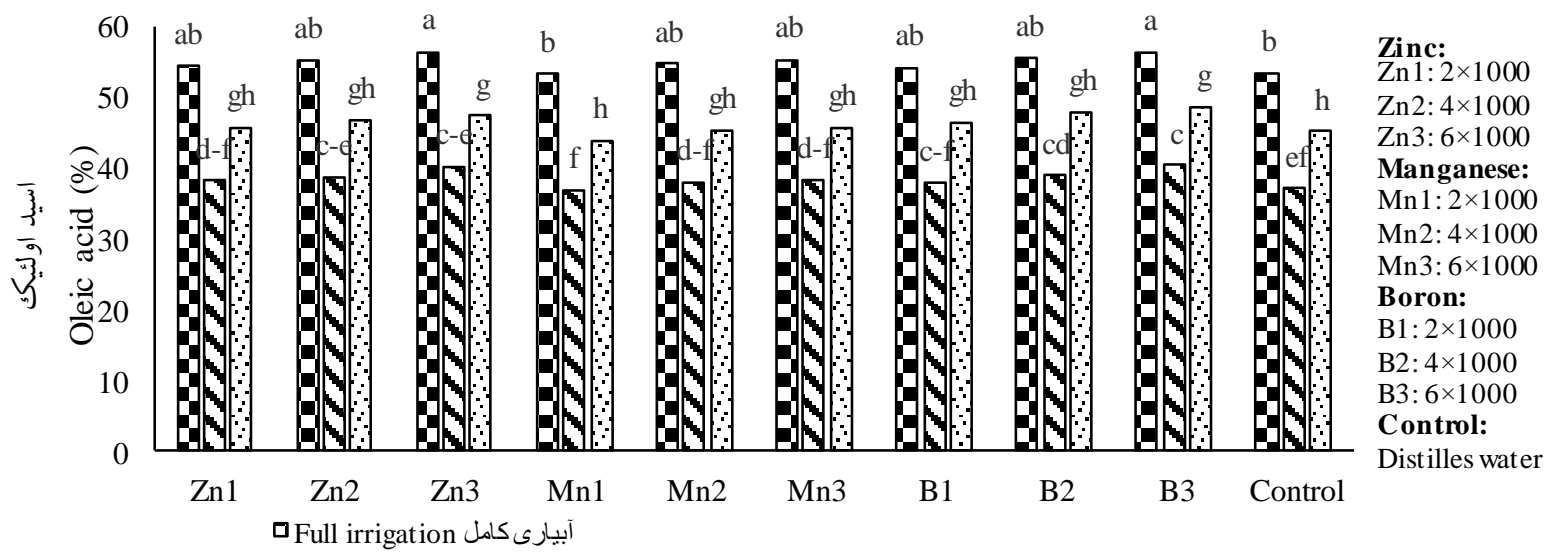

ه Irrigation withhold at flowering stage (Severe stress) قطع آبيارى در مرحله كلدهى (تنش شديد)

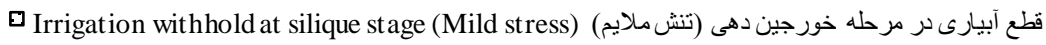

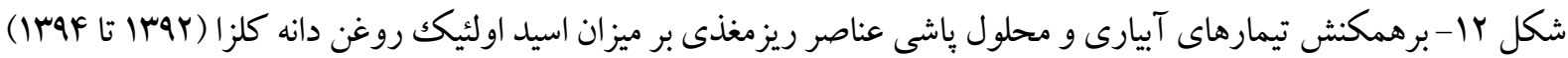

Fig. 12. Interaction effect of irrigation and foliar application of micro nutrient treatments on oleic acid content of seed of canola (2013-2015)

قطـع آبيـارى در مرحلـه كلـدهى بـود (جـدول r). بـر

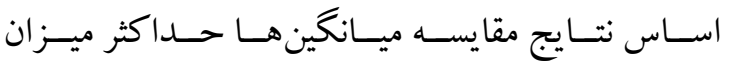
اسيد لينوليكك (YF/FN درصد) مربوط به تيمـار آبيـارى كامل و محلول يّاشى بُر (4 درهزار) بـود. حـداقل ميـزان

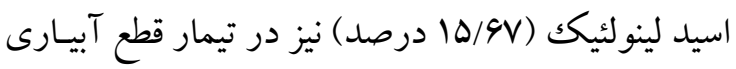
در مرحلـه خــورجيندهــى و عـــدم مصــرف عناصـر ريزمغذى بدست آمد. در شرايط قطع آبيارى در مرحله.

$$
\begin{aligned}
& \text { نتايج تجزيه واريانس مركب نشان داد كه اثر سـال، } \\
& \text { آبيـارى، محلـول ياشـى، سـال × آبيـارى و آبيـارى × } \\
& \text { محلـول ياشـى بــر ميـزان اسـيد لينولئيكك روغـن دانسه } \\
& \text { معنى دار بود. مقايسه ميـانكين هـا نشـان داد كـه بيشـترين } \\
& \text { (ميزان اسـيد لينولئك در سـال اول در (TF/Fq) } \\
& \text { تيمـار آبيـارى كامـل بدسـت آمــد. كمتــرين (هV) } \\
& \text { درصد) ميزان اسيد لينولئيك نيز در سال اول مربـوط بــ ليه }
\end{aligned}
$$




$$
\text { "نشريه علوم زراعى ايران"، جلد بيست و يكم، شماره با، باييز شهسا }
$$

تــنش شـــيد بــا يافتـههـــاى سانتونوســتو و همكــاران

(Santonoceto et al., 2003)

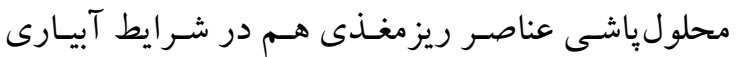
كامل و هم تنش باعـث افـزايش ميـزان اسـيد لينولئك كرديــ (شـكل 9). نتـايج يـك آزمـايش نشـان داد كـهـ مصرف سولفات روى به ميـزان ·و كيلـو گرم در هكتـار باعث افزايش ميزان اسيد لينولئيك در روغـن ينبـه دانسه

شد (Zakaria et al., 2006).

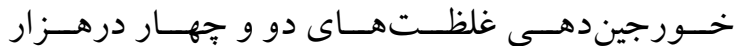
عناصر ريزمغذى روى و منكنز اثر معنىدارى بر افزايش اسيد لينولئيك نداشـتند (شـكل سا). تيمارهـاى آبيـارى باعث تغيير ميـزان اسـيدهاى جـرب اشـباع و غيـر اشـباع كرديد. اين روند به كونسهاى بـود كـه در شـرايط تسنش شديد (قطع آبيارى در مرحله كلدهى) ميـزان اسـيدهاى جرب يالميتيك، استئاريكك و اولئكك كاهش، اما ميـزان

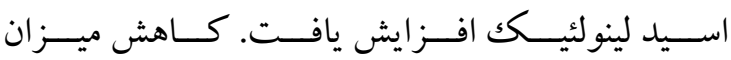
اسـيد اولئيـكك و افـزايش اســيد لينولئكـك در شــرايط

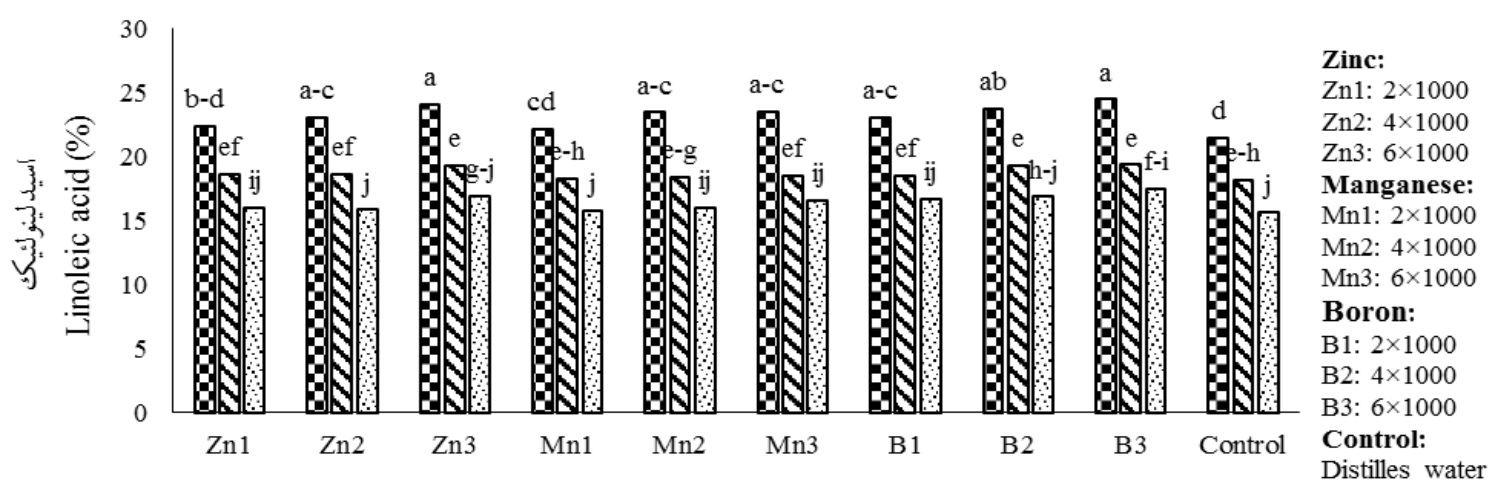

Tull irrigation بيارى كامل

ه Irrigation withhold at flowering stage (Severe stress) قطع آبيارى در مرحلد كلدهى (تنش شديد)

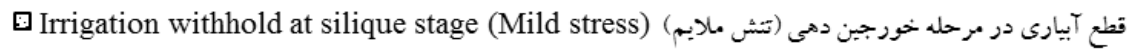

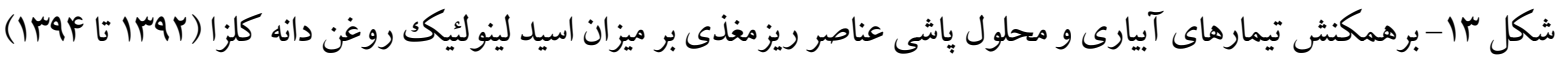

Fig. 13. Interaction effect of irrigation and foliar application of micro nutrient treatments on linoleic acid content of seed of canola (2013-2015)

بهبود دهد. قطع آبيارى در مراحل كلدهى (تنش شديد) و خـــورجين دهــى (تـــش ملايـــم) باعـــث كــاهش عملكـرد دانسه (بـه ترتيـب هو و ها درصــد) در كلـز ا شد. بر اساس نتـايج آزمـايش، قطع آبيـارى در مرحلـه كلدهى باعث وارد شدن تنش شديد به كيـاه كلز ا شـده

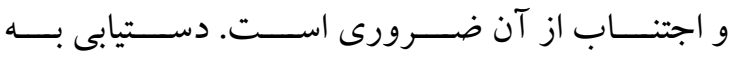
عملكرد مناسب دانسه كلـز ابـا اجـراى آبيـارى كامـل و

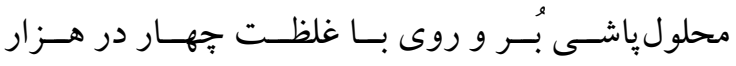
امكانيذير است.

$$
\text { سياسگز ارى }
$$

\section{نتيجه گيرى}

نتـايج ايسن آزمـايش نشـان داد كـه قطـع آبيـارى

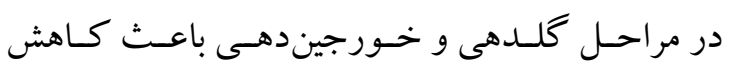
عملكـرد دانسه، روغـن دانـه و كـاهش ميـزان اسـيدهاى

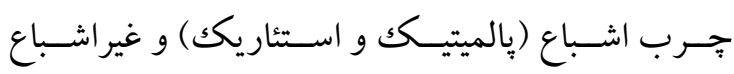

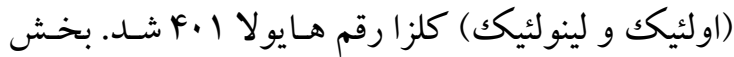

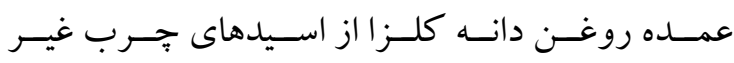
اشباع تشكيل شده است و وقوع تنش خشكى در مراحل زايشــى باعــث كــاهش كيفيــت روغــن مى شـــود. محلول ياشى عناصـر ريزمغـذى مسى توانــ ميـزان روغـن دانـه و ميـزان اسـيدهاى جـرب اولئيـك و لينولئكك را 


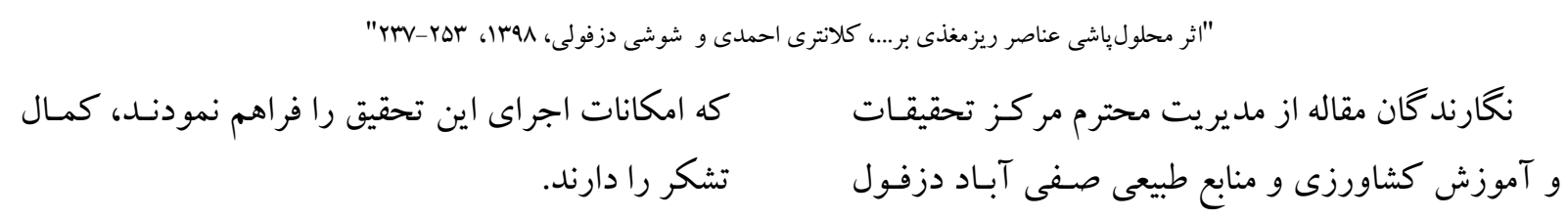

References

منابع مورد استفاده

Azadmard-Damirchi, S. and P. C. Dutta. 2008. Stability of minor lipid components with emphasis on phytosterols during chemical interesterification of a blend of refined olive oil and palm stearin. JAOCS. 85(1): 13-21.

Baldini, M., R. Giovanardi, S. Tahmasebi-Enferadi, and G. P. Vannozzi. 2002. Effects of water regime on fatty acid accumulation and final fatty acid composition in the oil of standard and high oleic sunflower hybrids. IJA. 6 (2): 119-126.

Bouchereau, A., N. Clossais-Besnard, A. Bensaoud, L. Leport and A. M.Renard. 1996. Water stress effects on rapeseed quality. Eur. J. Agron. 5: 19-30.

Habibi, M., M. Majidian and M. Rabiei. 2014. Effect of boron, zinc and sulfur elements on grain yield and fatty acid composition of rapeseed. Agric. Crop Manage. 16 (1): 69-84.

Hajiboland, R. and F. Amirazad. 2010. Drought tolerance in Zn-deficient red cabbage (Brassica oleracea L. var. capitata f. rubra) plants. Hort. Sci. 37: 88-98.

Jabeen, N. and R. Ahmad. 2011. Effect of foliar-applied boron and manganese on growth and biochemical activities in sunflower under saline conditions. Pak. J. Bot. 43: 1271-1282.

Kalantar Ahmadi, S. A., A. H. Shiranirad and S. A. Sidat. 2013. Study of limited irrigation stress on grain yield of canola cultivars in north Khouzestan conditions. J. Oil Plant Prod. 1: 53-65.

Kimber, D. S. and D. L. Mc Gregor. 1995. Brassica Oil Seeds: Production and Utilization. CAB international.

Kosaki, A., E. Psomiadau, M. Tsimidou, A. Rlopia, A. Tienonen and P. Kefalas. 2002. Oxidative salinity and minor constituents of virgin olive oil and rapeseed oil. Eur. Food Res. Technol. 214: 294-298.

Krupa, Z., and T. Baszynski. 1995. Some aspects of heavy metals toxicity towards photosynthetic apparatusdirect and indirect effects on light and dark reactions. Acta Physiologiae Plantarum, 2(17): 177-190.

Marschner, H. 1995. Mineral Nutrition of Higher Plants (2nd Ed.), Acedemic Press, London, UK.

Mei, Y., S. Lei., X. Fang-Sen, L. Wei and W. Yun-Hua. 2009. Effects of B, Mo, Zn, and their interactions on seed yield of rapeseed (Brassica napus L.). Pedosphere. 19 (1): 53-59.

Moghadam, H. R. T., H. Zahedi and F. Ghooshchi. 2011. Oil quality of canola cultivars in response to water stress and super absorbent polymer application. Pesqui. Agropecu. Trop. 41(4): 579-586.

Movahhedy-Dehnavy, M., S. A. M., Modarres-Sanavy and A. Mokhtassi-Bidgoli. 2009. Foliar application of zinc and manganese improves seed yield and quality of safflower (Carthamus tinctorius L.) grown under water deficit stress. Ind. Crop Prod. 30: 82-92.

Nadian, H., R. Najarzadegan, K. A. Saeid, M. H. Gharineh and A. Siadat. 2010. Effects of boron and sulfur 


$$
\text { "نشريه علوم زراعى ايران"، جلد بيست و يكم، شماره با، باييز بهسا }
$$

application on yield and yield components of Brassica napus L. in a calcareous soil. World Appl. Sci. J. 11: 89-95.

Ngouajio, M., G. Wang and R. Goldy. 2007. Withholding of drip irrigation between transplanting and flowering increases the yield of field-grown tomato under plastic mulch. Agric. Water Manage. 87: $285-291$.

Nielsen, D. C. and J. Janick, 1996. Potential of canola as a dryland crop in northeastern Colorado. Progress in new crops. ASHS Press, Alexandria, Virginia USA. Proceeding of the Third National Symposium Indianapolis. 22: 281-287.

Robertson, M. J. and J. F. Holland. 2004. Production risk of canola in the semi-arid subtropics of Australia. Aust. J. Agric. Res. 55 (5): 525-538.

Rood, S. B., D. J. Major and W. A. Charnetski. 1984. Seasonal changes in ${ }^{14} \mathrm{CO}_{2}$ assimilation and ${ }^{14} \mathrm{C}$ translocation in oilseed rape. Field Crop Res. 8: 341-348.

Santonoceto, C., U. Anastasi, E. Riggi and V. Abbate. 2003. Accumulation dynamics of dry matter, oil and major fatty acids in sunflower seeds in relation to genotype and water regime. Ital. J. Agron. 7(1): 3-14.

Sarkar, D., B. Mandal and M. C. Kundu. 2007. Increasing use efficiency of boron fertilizers by rescheduling the time and methods of application for crops in India. Plant Soil. 301: 77-85.

Sylvester-Bradley, R. and R. J. Makepeace. 1984. A code for stages of development in oilseed rape (Brassica napus L.). Asp. Appl. Biol. 6:399-418.

Tandon, H. L. S. 2005. Micronutrients in soils, crops and fertilizers. Fertilizer Development and Consultation Organization, New Delhi, India. pp: 138.

Yang, M., L. Shi., F. S. Xu and Y. H. Wang. 2009. Effect of boron on dynamic change of seed yield and quality formation in developing seed of Brassica napus. J. Plant Nutr. 32: 785-797.

Zakaria, M. S., S. A. Hafez, A. E. Basyony and A. E. R. Alkassas. 2006. Cottonseed, protein, oil yields and oil properties as affected by nitrogen fertilization and foliar application of potassium and a plant growth retardant. Agric. Sci. 2 (1): 56-65.

Zarei, G., H. Shamsi and S. M. Dehghani. 2010. The effect of drought stress on yield, yield components and seed oil content of three autumnal rapeseed cultivars (Brassica napus L.). J. Res. Agric. Sci. 6 (1): 29-37. 


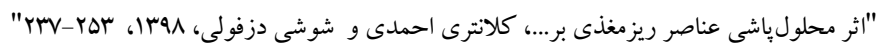

\title{
Effects of foliar application of micronutrients on seed yield and oil quality of canola (Brassica napus L. cv. Hyola401) under drought stress conditions
}

\author{
Kalantar Ahmadi. S.A. ${ }^{1}$ and A. A. Shoushi Dezfouli ${ }^{2}$
}

\begin{abstract}
Kalantar Ahmadi. S.A. and A. A. Shoushi Dezfouli. 2019. Effects of foliar application of micronutrients on seed yield and oil quality of canola (Brassica napus L. cv. Hyola401) under drought stress conditions. Iranian Journal of Crop Sciences. 21(3):237-253. (In Persian).
\end{abstract}

To evaluate the effects of drought stress by withholding of irrigation during reproductive stages and foliar application of micronutrients ( $\mathrm{Zn}, \mathrm{Mn}$ and B) on seed yiled and oil quality, an experiment was carried out as split plot arrangements in randomized complete block design with three replications at Safiabad Agricultural and Natural Resources Research and Education Center, Dezful, Iran, in two growing seasons (2013-2015). Main plots consisted of three irrigation levels: full irrigation (control), withholding of irrigation from flowering stage, and withholding of irrigation from silique stage, and sub plots included 10 levels of foliar application of micronutrients $(2,4,6 \%$ zinc, 2, 4, 6\% manganese, 2, 4, 6\%o boron, and the foliar application of distilled water as control). Foliar applications were made during both budding and initiation of flowering stages. Results showed that withholding of irrigation significantly decreased seed yield and yield components. Withholding of irrigation from flowering and silique stages reduced the silique no. plant ${ }^{-1}$ by $40 \%$ and $8 \%$, respectively. Mean comparison of withholding of irrigation and foliar application showed that the highest seed yield (4301 kg.ha-1) belonged to full irrigation and foliar application of boron (4\%o) in both growing seasons. The lowest seed yield (1863 kg.ha ${ }^{-1}$ ) obtained in withholding of irrigation from flowering stage and no micronutrient. Withholding of irrigation from flowering stage led to decrease oleic and linoleic acids content. The highest oil content (45.6\%) measured in full irrigation and application of zinc (6\%) and boron (6\%). The lowest oil content $(40.3 \%)$ observed in severe moisture stress conditions and no micronutrients. The results of this experiment showed that withholding of irrigation from flowering stage imposed severe stress on crop and should be avoided. The highest seed yield belonged to application of manganese and boron (4\%) and zinc (6\%) under withholding of irrigation from silique stage. To obtain reasonable seed yield, full irrigation and foliar application of zinc (4\%) and boron (4\%o) is possible.

Key words: Canola, Boron, Drought, Manganese, Oleic acid and Zinc.

\footnotetext{
Received: December, 2018 Accepted: November, 2019

1. Assistant Prof., Safiabad Agricultural and Natural Resources Research and Education Center, Agricultural Research, Education and Extension Organization (AREEO), Dezful, Iran (Corresponding author)

(Email: a.kalantarahmadi@areeo.ac.ir)

2. Assistant Prof., Safiabad Agricultural and Natural Resources Research and Education Center, Agricultural Research, Education and Extension Organization (AREEO), Dezful, Iran
} 